Provided for non-commercial research and education use. Not for reproduction, distribution or commercial use.

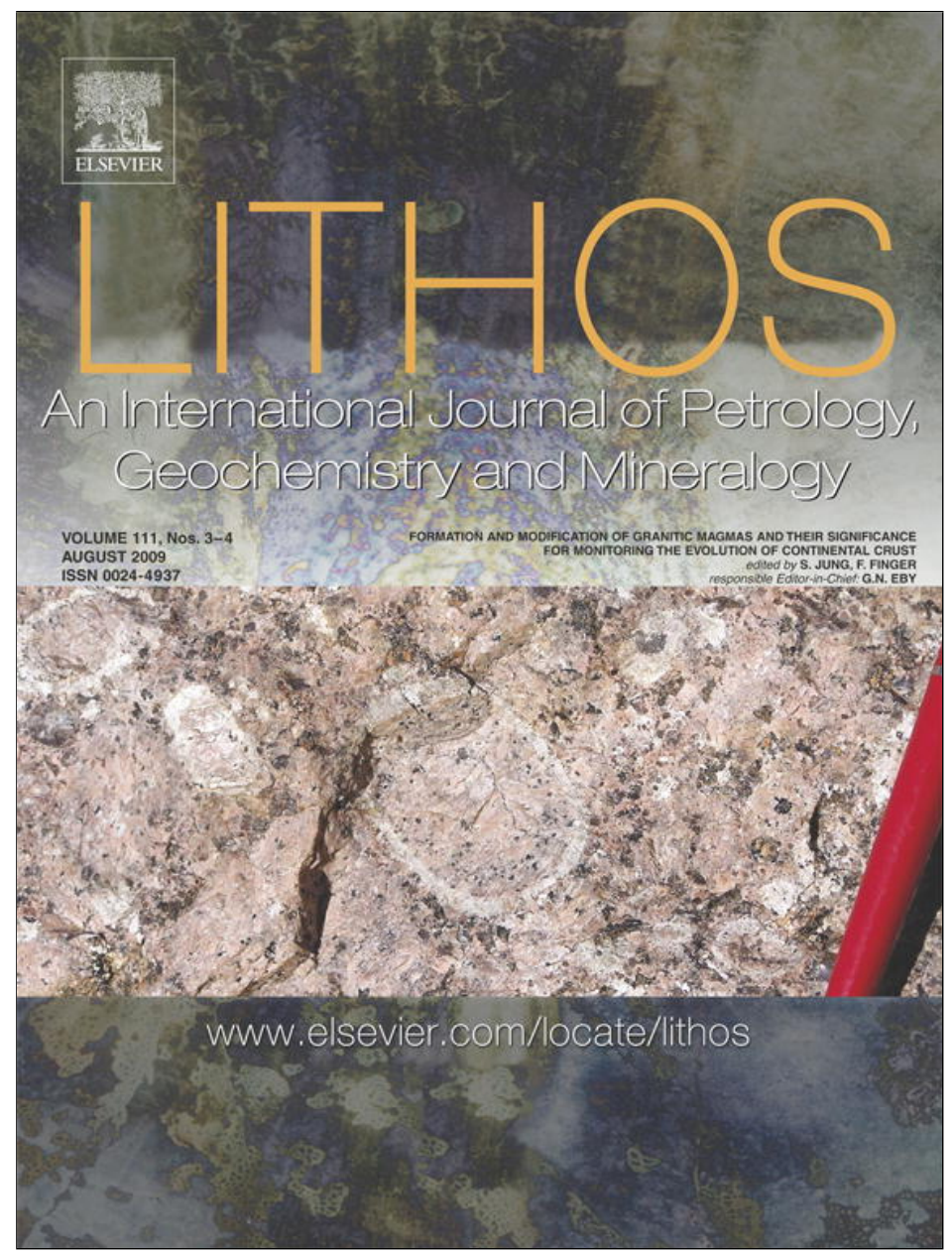

This article appeared in a journal published by Elsevier. The attached copy is furnished to the author for internal non-commercial research and education use, including for instruction at the authors institution and sharing with colleagues.

Other uses, including reproduction and distribution, or selling or licensing copies, or posting to personal, institutional or third party websites are prohibited.

In most cases authors are permitted to post their version of the article (e.g. in Word or Tex form) to their personal website or institutional repository. Authors requiring further information regarding Elsevier's archiving and manuscript policies are encouraged to visit:

http://www.elsevier.com/copyright 


\title{
U-Th-Pb SHRIMP ages and oxygen isotope composition of zircon from two contrasting late Variscan granitoids, Nisa-Albuquerque batholith, SW Iberian Massif: Petrologic and regional implications
}

\author{
A. Rita Solá a,*, Ian S. Williams ${ }^{\mathrm{b}}$, Ana M.R. Neiva ${ }^{\mathrm{c}}$, M. Luisa Ribeiro ${ }^{\mathrm{a}}$ \\ a Department of Geology, INETI, Apartado 7586, 2721-866 Alfragide, Portugal \\ ${ }^{\mathrm{b}}$ Research School of Earth Sciences, The Australian National University, Canberra, ACT 0200, Australia \\ c Department of Earth Sciences, University of Coimbra, 3000-272 Coimbra, Portugal
}

\section{A R T I C L E I N F O}

\section{Article history:}

Received 29 February 2008

Accepted 27 March 2009

Available online 14 April 2009

\section{Keywords:}

SHRIMP

Zircon

Oxygen isotopes

Granite magma genesis

Iberian Massif

Variscan

\begin{abstract}
A B S T R A C T
The late Variscan Nisa-Albuquerque batholith in the SW Iberian Massif, consists of a dominant very coarsegrained porphyritic S-type monzogranite to syenogranite (Nisa monzogranite) surrounding a discontinuous central core that includes contrasting very fine-grained I-type tonalite-granodiorite (Aldeia da Mata tonalite). The batholith is located at the boundary between the Central Iberian and Ossa-Morena Zones, a complex segment of crust that was subject to both Cadomian and Variscan tectonism. Variscan zircons in the Nisa monzogranite can be broadly classified into three texturally and chemically distinct types with mutually indistinguishable SHRIMP ${ }^{206} \mathrm{~Pb} /{ }^{238} \mathrm{U}$ ages: 1) high-U, low-Th/U $(<0.1)$ outermost overgrowths (307.4 \pm $4.0 \mathrm{Ma}) ; 2$ ) moderate $\mathrm{U}$ and $\mathrm{Th} / \mathrm{U}$ zircon with concentric zoning occurring both as inner overgrowths and whole grains (305.4 $\pm 6.2 \mathrm{Ma}) " ; ;$ and 3 ) texturally discordant cores (309.0 $\pm 4.6 \mathrm{Ma}$ ). Many other cores have ages in the ranges 2.56-1.85 and 0.66-0.51 Ga. The overgrowths and Variscan cores with low Th/U have uniformly high $\delta^{18} \mathrm{O}(9.5 \pm 0.2 \%)$. Variscan cores with moderate $\mathrm{Th} / \mathrm{U}$ have a wide range of $\delta^{18} \mathrm{O}(6.7-$ $10.9 \%$ ). Cores older than 500 Ma have an even wider range of composition (4.4-10.0\%). Zircon from the central Aldeia da Mata tonalite, in contrast, contains no inherited cores, has moderate to high Th/U $(0.5-1.8)$, and is uniform in ${ }^{206} \mathrm{~Pb} /{ }^{238} \mathrm{U}$ age $(306.2 \pm 3.0 \mathrm{Ma})$ and $\delta^{18} \mathrm{O}(7.4 \pm 0.3 \%$ ). The zircon in the Nisa monzogranite records a history of magma genesis involving mixing between 1) a metaluminous magma progressively contaminated by a small sedimentary component, and 2) a more voluminous peraluminous magma originating from a largely metasedimentary source. The inherited zircon age pattern closely matches the age pattern of detrital zircon in early Paleozoic sediments from North Africa. The zircon in the Aldeia da Mata tonalite records nothing of the age of the magma's source rocks, but the moderately high $\delta^{18} \mathrm{O}$ does preclude derivation of the magma directly from the mantle. Both the chemical and isotopic compositions of the tonalite zircon make it highly unlikely that the tonalite magma was a component in the monzogranite magma mixture.
\end{abstract}

(C) 2009 Elsevier B.V. All rights reserved.

\section{Introduction}

Precise dating of granites associated with orogenic processes, and studies of their petrogenesis, are essential to understanding the overall evolution of continents. The Iberian Massif represents a large segment of the European Variscan Belt (e.g., Ribeiro et al., 1990), interpreted to have formed during Early Devonian to Carboniferous oblique continental collision (e.g., Matte, 1986, 1991). One of the important features of the Iberian Massif is the huge volume of granitic rocks, particularly in the innermost domains (Central Iberian Zone, Fig. 1A). Most of the Central Iberian Zone granitoids are related to the

\footnotetext{
* Corresponding author. Tel.: +351 214705438; fax: +351 214719018 E-mail address: rita.sola@ineti.pt (A.R. Solá).
}

post-collisional stage $\left(D_{3}\right)$ of the Variscan deformation (e.g., Ferreira et al., 1987). Several granitoids have been dated isotopically by means of Rb-Sr, K-Ar and/or ID-TIMS U-Pb (e.g., Pinto et al., 1987; Dias et al., 1998; Neiva and Gomes, 2001; Valle Aguado et al., 2005). According to their emplacement ages and relationships to late deformation, the granitoids have been classified as syn- $\mathrm{D}_{3}$, late- $\mathrm{D}_{3}$, late- to post- $\mathrm{D}_{3}$ and post-D ${ }_{3}$ (Ferreira et al., 1987; Dias et al., 1998), or syntectonic to latetectonic (c. 336-304 Ma) and post-tectonic (c. 300-280 Ma) granites (Neiva and Gomes, 2001) respectively. Sometimes this classification conflicts with other geological evidence, however (Dias et al., 1998; Zeck et al., 2007). This, as well as the known limitations of Rb-Sr and $\mathrm{K}-\mathrm{Ar}$ isotopic systems (e.g. low closure temperatures) and also IDTIMS zircon $\mathrm{U}-\mathrm{Pb}$ dating (e.g. susceptibility to inheritance and radiogenic $\mathrm{Pb}$ loss) (Zeck et al., 2007 and references therein) has prompted us to measure the ages of granitoids from a late-tectonic 


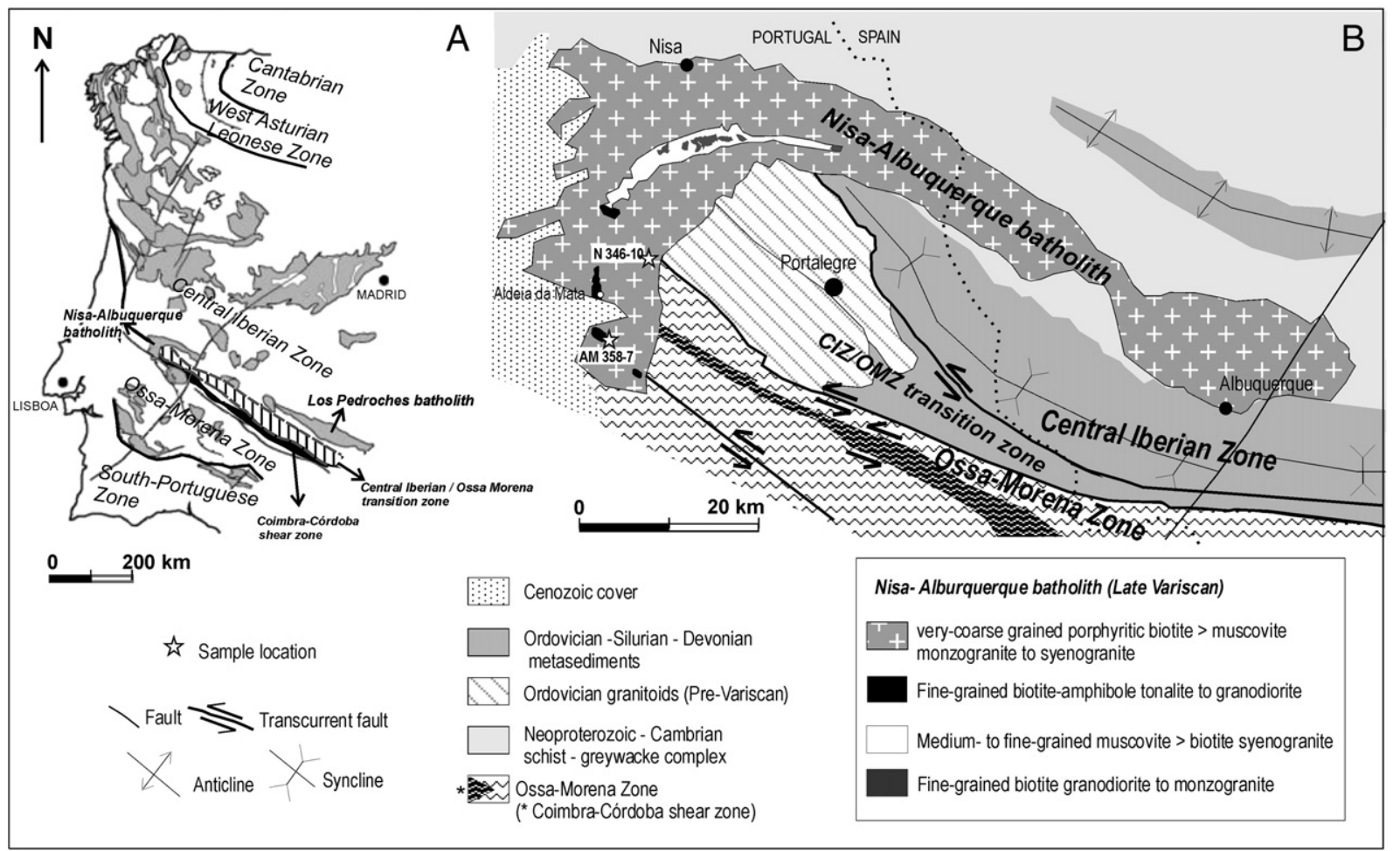

Fig. 1. A. Sketch of the distribution of Variscan granite batholiths in Iberia (modified after Bea et al., 1999) and geological setting of area B located at the boundary between the Central Iberian and Ossa-Morena Zones. B. Simplified geological map of the Nisa-Albuquerque batholith and its host rocks (modified from the Geological map of Portugal, 1992; Moreira, 1994; Pereira and Silva, 2001; Geological map of Spain, 2004)

batholith by sensitive high resolution ion microprobe (SHRIMP) in situ zircon U-Th-Pb dating. Moreover, the refractory character of zircon allows us to get information on the possible provenance and nature of the magma sources (from zircon cores) and the ages of post-magmatic events (from late zircon overgrowths). The oxygen isotopic compositions measured on the same spots provide valuable information on the magma genesis.

The Nisa-Albuquerque batholith, the subject of the present study, has several interesting features: 1 ) it cuts the Central Iberian/OssaMorena Transition Zone (Fig. 1) and the Coimbra-Córdoba shear zone, a major high-grade transcurrent structure of the Ossa-Morena Zone (e.g., Burg et al., 1981; Eguiluz et al., 2000; Pereira and Silva, 2001; Silva and Pereira, 2004; Pereira et al., 2008a); 2) it has a concentric zonation: a dominant S-type monzogranite-syenogranite, the Nisa monzogranite, surrounds a contrasting very fine-grained discontinuous central core of I-type tonalite-granodiorite, the Aldeia da Mata tonalite (Fig. 1B); and 3) it is closely associated with uranium mineralization, mainly in the contact metamorphic aureole.

According to previous $\mathrm{Rb}-\mathrm{Sr}$ and $\mathrm{K}-\mathrm{Ar}$ age measurements, the Nisa-Albuquerque batholith was emplaced at 312-286 Ma (Mendes, 1967-1968, Penha and Arribas, 1974; Roberts et al., 1991; González Menéndez, 2002). Here we present SHRIMP zircon U-Th-Pb analyses from two intrusions from the batholith that further constrain the ages and petrologic relationships of the I- and S-type granite association, as well as the timing of the Variscan deformation in the SW Iberian Massif. Moreover, the analyses and zircon growth textures are used to assess the processes that were active during crystallization of the magmas, relating zircon growth zoning and chemical characteristics to thermal and chemical changes in the magma during crystallization.

Zircon oxygen isotopic compositions were subsequently measured by SHRIMP on many of the same spots on the same grains analysed for $\mathrm{U}-\mathrm{Th}-\mathrm{Pb}$. Zircon effectively preserves a record of the oxygen isotopic composition of the magma from which it crystallized (Valley, 2003), providing valuable information about the magma source (metasedimentary, meta-igneous, mantle). The oxygen isotope variations in zircon populations, combined with zircon ages, growth textures and chemical compositions, are a useful tool for tracing the nature and evolution of granite magmas and their sources.

\section{Geological setting and previous work}

The Nisa-Albuquerque batholith forms part of the regional NisaLos Pedroches NW-SE magmatic alignment, located in the southernmost sector of the Central Iberian Zone (Fig. 1A). It is a composite, elongate body exposed over an area of $1000 \mathrm{~km}^{2}$ in central Portugal and Spain, oriented parallel to, and crossing, the southern boundary of the Central Iberian Zone (Fig. 1). In the north, the batholith intruded metasediments of the Schist-Greywacke complex (NeoproterozoicCambrian) and produced a contact metamorphic aureole 800-1200 m wide (Campos and Pereira, 1991) that consists of cordierite schists and pelitic and quartz-pelitic hornfelses. The contact between the batholith and its host rocks is sharp and vertical. Towards the south, the granitoids intruded an Ordovician to Devonian sedimentary sequence of the Castelo de Vide-Albuquerque syncline. Near Nisa (Portugal) the granitoids, which have an arcuate shape, intruded Ordovician granitoids and Ossa-Morena Zone rocks including the CoimbraCórdoba shear zone. A late-stage fracture system affected the batholith, producing several N-S faults (Campos and Pereira, 1991). Intrabatholithic and peri-batholithic tungsten, phosphorous and mainly uranium mineralization is associated with the batholith (Neiva et al., 1952; Faria and Mesquita, 1962; Pilar, 1966; Neiva, 2003).

The Nisa-Albuquerque batholith consists of a dominant peraluminous coarse-grained porphyritic, two-mica monzogranite to syenogranite (S-type affinity) that occupies over $85 \%$ of the outcrop area and shows a marked differentiation from west to east (Solá et al., 1998a; González Menéndez, 2002). In the core, there are three generally finer-grained granitoids that clearly contrast with the host granite, forming a discontinuous alignment with the same arcuate shape as the batholith (Moreira, 1994; Fig. 1B). In order of increasing $\mathrm{SiO}_{2}$ content they are: 1 ) a fine-grained biotite-amphibole tonalite to 
granodiorite (I-type affinity); 2) a fine-grained biotite granodiorite to monzogranite (I-type affinity); and 3) a medium- to fine-grained muscovite $>$ biotite syenogranite (S-type affinity) (Fig. 1B). Petrographic features and Anisotropy of the Magnetic Susceptibility (ASM) data favour an intrusion of the 'core granites' inside the external granite through a central fault (e.g., Ribeiro et al., 1995; Solá et al., 1997, 1998a). Moreover, the cross-cutting relationships between the core granites and the external granite provide evidence for magma mixing and re-intrusion processes, especially in the eastern sector, suggesting that cooling of the batholith progressed from west to east (González Menéndez and Azor, 2006). The core granites have geochemical features that contrast with those of the outer host granite, indicating that the inner and outer granites crystallized from unrelated magma batches, probably generated from two main sources (I- and S-type affinity; Solá et al., 1998a; González Menéndez, 2002; Solá, 2007). However the petrologic processes responsible for this zonation remain poorly understood.

The Nisa-Albuquerque batholith was initially reported to be a posttectonic (post- $\mathrm{D}_{3}$ ) intrusion (Ferreira et al., 1987). Based on tectonic studies, Pereira et al. (1998) suggested that the batholith was emplaced by a pull-apart mechanism related to the late Variscan regional deformation (late- $\mathrm{D}_{3}$ ). Several ages have been measured previously, but only on the dominant outer granitoid. $\mathrm{Rb}-\mathrm{Sr}$ biotite ages of $290 \pm 8$ and $301 \pm 9$ Ma (Mendes, 1967-1968) from the western part of Nisa-Albuquerque batholith, recalculated using the decay constant recommended by Steiger and Jäger (1977), are $300 \pm 8$ and $312 \pm 9 \mathrm{Ma}$, respectively. $\mathrm{K}-\mathrm{Ar}$ ages for biotites and muscovites (Penha and Arribas, 1974) from the eastern part of the batholith, Albuquerque, Spain, when recalculated are $293 \pm 10$ and $287 \pm 10 \mathrm{Ma}$, respectively. There is also a $\mathrm{Rb}-\mathrm{Sr}$ whole-rock age of $286 \pm 3.6 \mathrm{Ma}$ reported by Roberts et al. (1991), and González Menéndez (2002) reported a $\mathrm{Rb}-\mathrm{Sr}$ whole-rock isochron giving $294 \pm 11 \mathrm{Ma},\left({ }^{87} \mathrm{Sr} /\right.$ $\left.{ }^{86} \mathrm{Sr}\right)_{0}=0.7128 \pm 0.0031, \mathrm{MSWD}=1.1$, and an errorchron giving $289 \pm$ $22 \mathrm{Ma},\left({ }^{87} \mathrm{Sr} /{ }^{86} \mathrm{Sr}\right)_{0}=0.7105 \pm 0.0070, \mathrm{MSWD}=10$ from NNW of Albuquerque, Spain.

\section{SHRIMP zircon $\mathrm{U}-\mathrm{Th}-\mathrm{Pb}$ and oxygen isotopic data}

\subsection{Description of the selected samples}

Two samples were selected for zircon analysis (see locations on Fig. 1B): one from the dominant (external) Nisa monzogranite (sample N 346-10; UTM coordinates 29SPD166577) and one from the Aldeia da Mata tonalite located in the core of the batholith (sample AM 358-7; UTM coordinates 29SPD117471).

Sample N 346-10 is a monzogranite with $\mathrm{SiO}_{2}=71.9$ wt.\% and A/ $\mathrm{CNK}=1.16$. It has a subhedral granular texture and contains large phenocrysts (locally up to $90 \times 20 \mathrm{~mm}$ ) of plagioclase and K-feldspar. The plagioclase phenocrysts (2-26 mol\% An) have strongly zoned, relatively calcic cores that preserve a pattern of deformation/

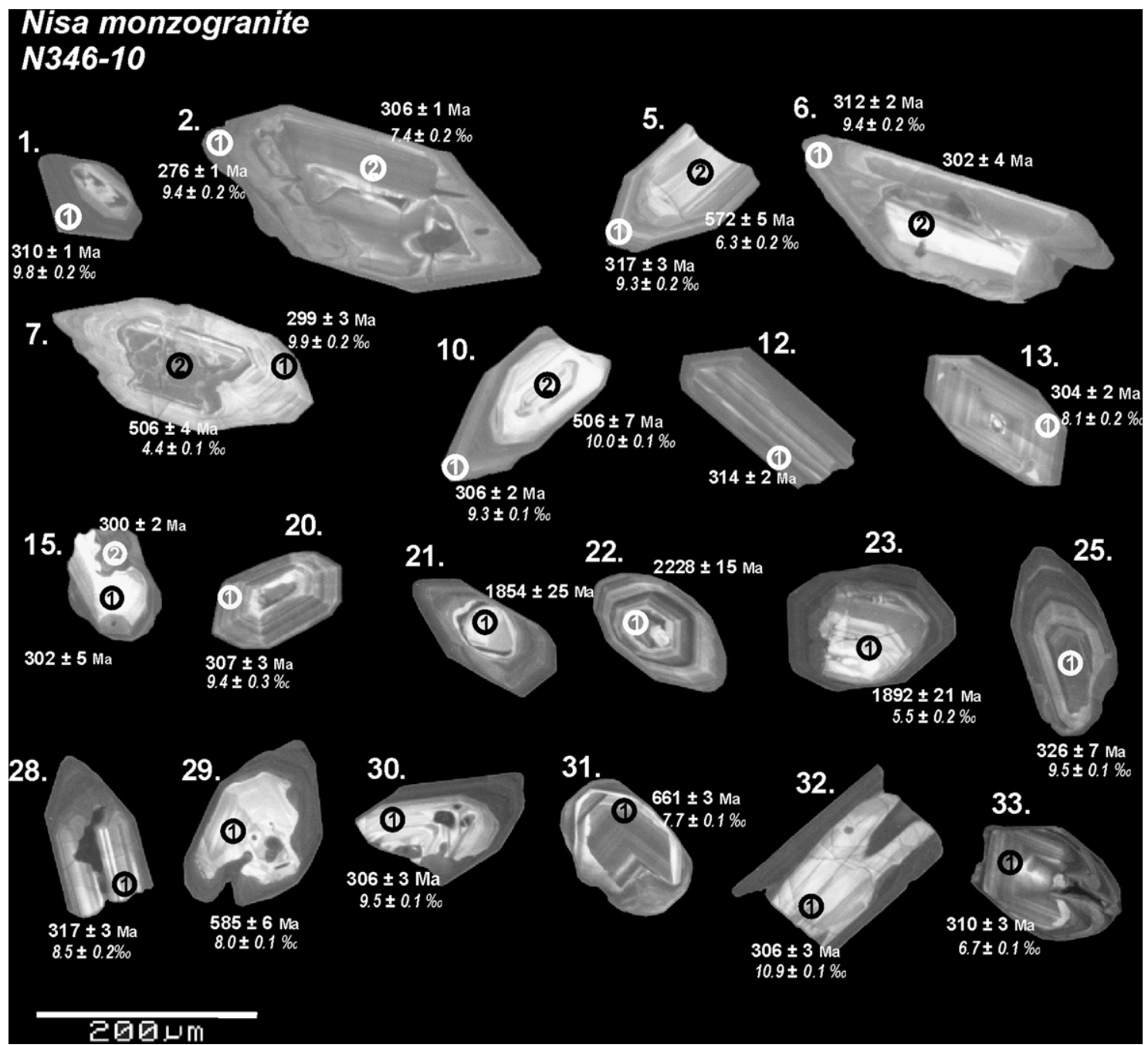

Fig. 2. Cathodoluminescence images of analysed zircon grains from the Nisa monzogranite (sample N 346-10) showing the variety of crystal morphologies, zoning, cores and growth structures. Grain numbers, spots, and ${ }^{206} \mathrm{~Pb} /{ }^{238} \mathrm{U}$ ages $(\mathrm{Ma})$ and $\delta^{18} \mathrm{O}(\%)$ refer to Tables 1 and 3. 
alteration predating that of the more sodic rims (Solá et al., 1998b). The sample consists of approximately $35 \%$ quartz, 30\% plagioclase, $20 \%$ perthitic K-feldspar, $8 \%$ biotite and $4 \%$ muscovite. Zircon, apatite, monazite, ilmenite, rutile and locally tourmaline are the main accessory minerals. Rare andalusite and cordierite are also present. Secondary titanite, chlorite, muscovite and clay minerals occur locally.

Sample AM 358-7 is a tonalite with $\mathrm{SiO}_{2}=60.6$ wt.\% and $\mathrm{A} /$ $\mathrm{CNK}=0.93$. It is equigranular and has a fine-grained texture. It consists of approximately $25 \%$ quartz, $40 \%$ strongly zoned plagioclase (22-52 mol\% An), 10\% K-feldspar, 15\% biotite, 10\% hornblende, 5\% titanite, and accessory allanite, epidote, zircon, thorite, apatite, ilmenite and sulphides. Secondary chlorite and carbonates occur locally.

\subsection{Sample preparation and analytical procedures}

The zircon separations, SEM cathodoluminescence (CL) imaging and SHRIMP analyses were carried out at the Research School of Earth Sciences (Australian National University, Canberra). A representative selection of grains from each sample was hand-picked and cast in epoxy resin together with zircon standards SL13 $(U=238 \mathrm{ppm})$ and Temora $\left({ }^{206} \mathrm{~Pb}^{*} /{ }^{238} \mathrm{U}=0.06683\right)$. The mount was polished to expose the grain interiors, photographed at high magnification in transmitted and reflected light, and then imaged by SEM CL (Figs. 2 and 3) to document the internal growth zoning of the grains. The mount was then cleaned and coated with high purity Au. Selected areas in the grains were analysed for $\mathrm{U}$, Th and $\mathrm{Pb}$ isotopes on the SHRIMP II using a procedure similar to that described by Williams and Claesson (1987). The spots for analysis were selected to avoid textural complexity, fractures and inclusions and that was verified after the SHRIMP analytical session using secondary electron imaging. A $10 \mathrm{kV}$ negative $\mathrm{O}_{2}$ primary beam was focused to c. $25 \mu \mathrm{m}$ diameter. Positive secondary ions were extracted at $10 \mathrm{kV}$ and mass analysed at c. R5000 on a single ETP multiplier by peak stepping through the isotopes of interest.

The U-Th-Pb analyses are listed in Tables 1 and 2 and plotted on Tera-Wasserburg concordia diagrams in Figs. 4 and 5. Uncertainties

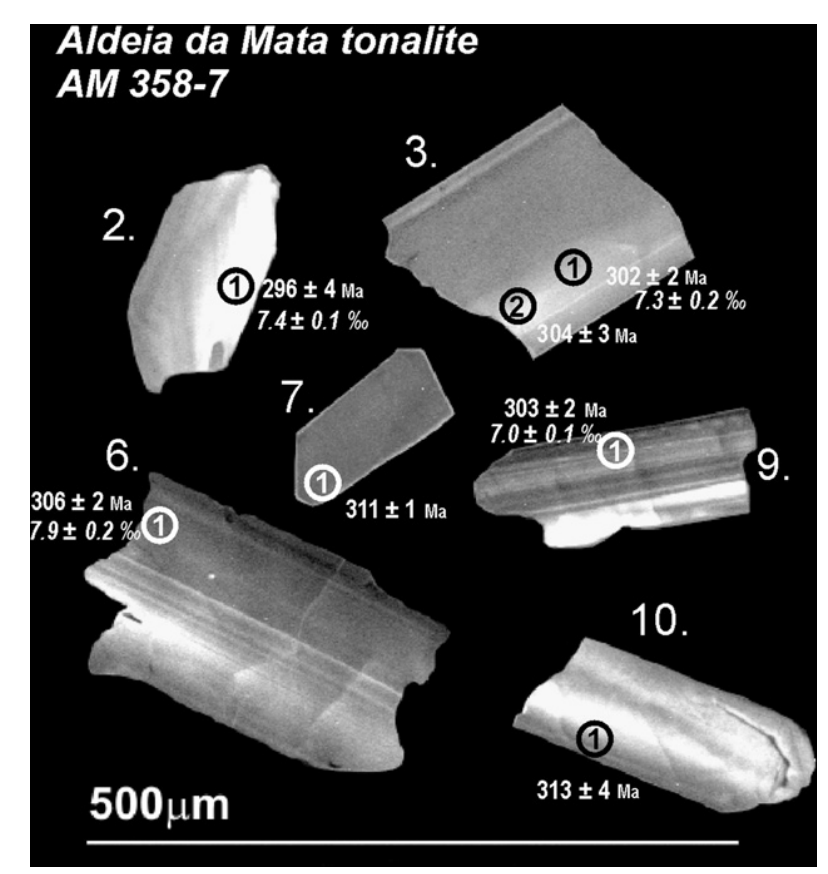

Fig. 3. Cathodoluminescence images of analysed zircon grains from the Aldeia da Mata tonalite (sample AM 358-7) showing the more uniform textures and absence of inherited cores. Grain numbers, spots, and ${ }^{206} \mathrm{~Pb} /{ }^{238} \mathrm{U}$ ages (Ma) and $\delta^{18} \mathrm{O}(\%)$ refer to Tables 2 and 3. listed and plotted are $1 \sigma$ precision estimates, calculated from counting errors and the propagation of uncertainties introduced by the common $\mathrm{Pb}$ correction. All analyses listed and plotted were corrected for common $\mathrm{Pb}$ using the measured ${ }^{204} \mathrm{~Pb}$ and a common $\mathrm{Pb}$ composition appropriate to the approximate age of the analysed spot (Cumming and Richards, 1975). The ${ }^{206} \mathrm{~Pb} /{ }^{238} \mathrm{U}$ ages are preferred because they have smaller uncertainties than the ${ }^{207} \mathrm{~Pb} /$ ${ }^{206} \mathrm{~Pb}$ and ${ }^{208} \mathrm{~Pb} /{ }^{232} \mathrm{Th}$ ages. Mean ${ }^{206} \mathrm{~Pb} /{ }^{238} \mathrm{U}$ ages were calculated after correcting for common $\mathrm{Pb}$ using ${ }^{207} \mathrm{~Pb}$, assuming concordance. Uncertainties in the mean ages are $95 \%$ confidence limits ( $t \sigma$, where $t$ is the Student's $t$ multiplier) and include the uncertainty in the $\mathrm{Pb} / \mathrm{U}$ calibration (c. 0.3\%). Ages were calculated using the constants recommended by the IUGS Subcommission on Geochronology (Steiger and Jäger, 1977). Analyses of $\mathrm{Pb} / \mathrm{U}$ in zircon with $\mathrm{U}$ contents above $2500 \mathrm{ppm}$ were corrected for a small U-related matrix effect using the procedure outlined by Butera et al. (2001).

Oxygen isotopic compositions were subsequently measured by SHRIMP II on many of the same areas of the same grains after recasting the mount and polishing it lightly to remove the oxygen implanted during the $\mathrm{U}-\mathrm{Th}-\mathrm{Pb}$ dating. The compositions were measured relative to zircon standard Temora ( $\delta^{18} \mathrm{O}=8.2 \%$ 。VSMOW; Valley 2003) using $15 \mathrm{kV} \mathrm{Cs}^{+}$primary ions and multiple collection and analytical procedures described in detail by Ickert et al. (2008). The results are listed in Table 3 and plotted in Fig. 6. The uncertainties listed and plotted are $2 \sigma$ precision estimates based on 14 successive measurements of the ${ }^{18} \mathrm{O} /{ }^{16} \mathrm{O}$ of each spot. Uncertainties in the average $\delta^{18} \mathrm{O}$ values are $95 \%$ confidence limits based on analyses of several grains and include the uncertainty in the concurrent analysis of the Temora zircon standard. After the oxygen analyses, the sample was again imaged by $\mathrm{CL}$, and the few analyses representing a mixture of core and rim zircon were discarded.

\subsection{Zircon morphology and zoning}

\subsubsection{Nisa monzogranite ( $N$ 346-10)}

The zircon in the monzogranite occurs in a wide variety of forms. Most of the grains $(\sim 60 \%)$ are medium to large $(100-200 \mu \mathrm{m}$ diameter), stubby and subhedral to euhedral, with well-developed $\{211\}$ pyramid faces, a common feature of zircon grains that contain an older core (Williams, 2001). Rare grains have multipyramidal terminations. The grains range from transparent colourless to translucent yellow-brown, and are commonly highly fractured and moderately rich in inclusions. Many are visibly zoned, and appear to contain a core. The remainder of the grains are finer $(<100 \mu \mathrm{m}$ diameter), relatively clear and colourless, more elongate (aspect ratio 2:6) and with simple $\{110\}$ or weakly developed $\{211\}$ terminations. They generally have less inclusions and fractures.

CL imaging shows that all grains are zoned and most have complex internal textures (Fig. 2). Most of the large, stubby grains consist of a large core surrounded by a texturally distinct overgrowth. The cores have a wide range of textures and CL response. Most of the cores are irregularly-shaped crystal fragments with moderate to weak CL (Fig. 2, grains 2,7 ). Some have very strong CL (Fig. 2, grains $15,29,30$ ). Zoning in the cores ranges from simple banding (Fig. 2, grain 28), to fine, concentric oscillatory zoning (Fig. 2, grains 31,33 ), to sinuous zoning, to indistinct (Fig. 2, grain 21). Some cores are almost euhedral (Fig. 2, grain 22 ), others are deeply embayed, apparently by partial dissolution (Fig. 2, grains 15, 29, 30). In the former case, the boundary between core and overgrowth can be difficult to distinguish. Most of the overgrowths have weak to very weak CL (Fig. 2, grains 1 ). Where developed on blunt ends of cores, the overgrowth textures can be very complex, consisting of multiple pyramids or sinuous zones. This overgrowth in turn is commonly overgrown by a relatively thin layer of zircon with simpler zoning. On subhedral cores, the zoning is simpler. If the core has a relatively simple shape, the overgrowth 
Table 1

SHRIMP U-Th-Pb isotopic analyses of zircon from the Nisa monzogranite N 346-10 (W sector of Nisa-Albuquerque batholith),

\begin{tabular}{|c|c|c|c|c|c|c|c|c|c|c|c|c|c|c|c|c|c|c|c|c|c|c|c|c|}
\hline \multicolumn{2}{|l|}{ Grain } & \multirow{2}{*}{$\begin{array}{l}\mathrm{Pb}^{\mathrm{a}} \\
\mathrm{ppm}\end{array}$} & \multirow{2}{*}{$\begin{array}{l}\mathrm{U} \\
\mathrm{ppm}\end{array}$} & \multirow{2}{*}{$\begin{array}{l}\text { Th } \\
\text { ppm }\end{array}$} & \multirow[t]{2}{*}{$\mathrm{Th} / \mathrm{U}$} & \multirow{2}{*}{$\begin{array}{l}{ }^{204} \mathrm{~Pb} \\
\mathrm{ppb}\end{array}$} & \multirow{2}{*}{$\begin{array}{l}{ }^{204} \mathrm{~Pb} / \\
{ }^{206} \mathrm{~Pb}\end{array}$} & \multirow[t]{2}{*}{ \pm} & \multirow{2}{*}{$\begin{array}{l}{ }^{208} \mathrm{~Pb}^{\mathrm{a}} / \\
{ }^{206} \mathrm{~Pb}\end{array}$} & \multirow[t]{2}{*}{ \pm} & \multirow{2}{*}{$\begin{array}{l}{ }^{208} \mathrm{~Pb}^{\mathrm{a} /} \\
{ }^{232} \mathrm{Th}\end{array}$} & \multirow[t]{2}{*}{ \pm} & \multirow{2}{*}{$\begin{array}{l}206 \mathrm{~Pb}^{\mathrm{a}} / / \\
{ }^{238} \mathrm{U}\end{array}$} & \multirow[t]{2}{*}{ \pm} & \multirow{2}{*}{$\begin{array}{l}{ }^{207} \mathrm{~Pb}^{\mathrm{a} /} \\
{ }^{235} \mathrm{U}\end{array}$} & \multirow[t]{2}{*}{ \pm} & ${ }^{207} \mathrm{~Pb}^{\mathrm{a}} /$ & \pm & Apparent ag & $\mathrm{s}(\mathrm{Ma})$ & & & & \\
\hline Spot & Type & & & & & & & & & & & & & & & & & & ${ }^{208} \mathrm{pb} /{ }^{232} \mathrm{Th}$ & \pm & ${ }^{6 / \mathrm{Pb}}$ & \pm & $\mathrm{Pb}$ & \pm \\
\hline 26.1 & DrkUZCo & 532 & 1453 & 951 & 0.65 & 33 & 0.000084 & 0.000008 & 0.1817 & 0.0013 & 0.0874 & 0.0010 & 0.3150 & 0.0023 & 7.376 & 0.087 & 0.1699 & 0.0014 & 1694 & 18 & 1765 & 11 & 2556 & 14 \\
\hline 22.1 & DrkUZCo & 135 & 459 & 103 & 0.23 & 1 & 0.000007 & 0.000011 & 0.0943 & 0.0010 & 0.1160 & 0.0036 & 0.2772 & 0.0069 & 5.354 & 0.147 & 0.1401 & 0.0012 & 2218 & 66 & 1577 & 35 & 2228 & 15 \\
\hline 14.1 & LtUZCo & 32 & 211 & 252 & 1.20 & 24 & 0.001001 & 0.000255 & 0.2429 & 0.0104 & 0.0259 & 0.0012 & 0.1278 & 0.0015 & 2.140 & 0.081 & 0.1214 & 0.0042 & 517 & 23 & 776 & 8 & 1977 & 63 \\
\hline 23.1 & LtCZCo & 44 & 114 & 68 & 0.59 & 1 & 0.000016 & 0.000018 & 0.1739 & 0.0019 & 0.1022 & 0.0020 & 0.3469 & 0.0047 & 5.535 & 0.105 & 0.1157 & 0.0013 & 1967 & 37 & 1920 & 23 & 1892 & 21 \\
\hline 21.1 & LtUZCo & 54 & 170 & 49 & 0.29 & 3 & 0.000062 & 0.000039 & 0.0732 & 0.0027 & 0.0786 & 0.0034 & 0.3079 & 0.0057 & 4.813 & 0.118 & 0.1134 & 0.0016 & 1530 & 63 & 1730 & 28 & 1854 & 25 \\
\hline 31.1 & DrkCZCo & 115 & 926 & 829 & 0.90 & 1 & 0.000013 & 0.000007 & 0.2719 & 0.0015 & 0.0328 & 0.0003 & 0.1081 & 0.0006 & 0.916 & 0.008 & 0.0615 & 0.0004 & 653 & 5 & 661 & 3 & 657 & 13 \\
\hline 24.1 & LtCZCo & 14 & 128 & 54 & 0.42 & 2 & 0.000181 & 0.000070 & 0.1258 & 0.0038 & 0.0310 & 0.0012 & 0.1037 & 0.0018 & 0.839 & 0.027 & 0.0586 & 0.0015 & 617 & 23 & 636 & 11 & 553 & 56 \\
\hline 29.1 & MedCZCo & 16 & 164 & 77 & 0.47 & 0 & 0.000020 & 0.000020 & 0.1433 & 0.0039 & 0.0289 & 0.0009 & 0.0949 & 0.0010 & 0.793 & 0.021 & 0.0606 & 0.0014 & 576 & 17 & 585 & 6 & 625 & 52 \\
\hline 5.2 & MedBCo & 25 & 237 & 207 & 0.87 & 1 & 0.000064 & 0.000027 & 0.2702 & 0.0041 & 0.0287 & 0.0005 & 0.0928 & 0.0008 & 0.739 & 0.014 & 0.0578 & 0.0009 & 571 & 10 & 572 & 5 & 520 & 34 \\
\hline 8.2 & MedCZCo & 22 & 264 & 64 & 0.24 & 9 & 0.000443 & 0.000080 & 0.0727 & 0.0035 & 0.0257 & 0.0013 & 0.0858 & 0.0009 & 0.667 & 0.020 & 0.0563 & 0.0015 & 514 & 25 & 531 & 5 & 466 & 61 \\
\hline 10.2 & LtCZCo & 17 & 218 & 38 & 0.17 & 1 & 0.000047 & 0.000039 & 0.0510 & 0.0021 & 0.0241 & 0.0011 & 0.0817 & 0.0011 & 0.623 & 0.019 & 0.0553 & 0.0014 & 481 & 21 & 506 & 7 & 425 & 58 \\
\hline 7.2 & DrkWZCo & 95 & 1271 & 130 & 0.10 & 49 & 0.000545 & 0.000042 & 0.0085 & 0.0017 & 0.0068 & 0.0014 & 0.0816 & 0.0006 & 0.667 & 0.013 & 0.0593 & 0.0010 & 136 & 28 & 506 & 4 & 576 & 37 \\
\hline 25.1 & DrkSZCo & 86 & 1826 & 36 & 0.020 & 3 & 0.000035 & 0.000016 & 0.0028 & 0.0007 & 0.0074 & 0.0018 & 0.0518 & 0.0011 & 0.371 & 0.009 & 0.0519 & 0.0004 & 149 & 36 & 326 & 7 & 282 & 18 \\
\hline 28.1 & MedBCo & 21 & 404 & 198 & 0.49 & 2 & 0.000130 & 0.000075 & 0.1478 & 0.0047 & 0.0151 & 0.0005 & 0.0504 & 0.0005 & 0.351 & 0.010 & 0.0506 & 0.0014 & 304 & 10 & 317 & 3 & 221 & 63 \\
\hline 12.1 & DrkB?Co & 69 & 1453 & 316 & 0.22 & 3 & 0.000054 & 0.000022 & 0.0607 & 0.0012 & 0.0140 & 0.0003 & 0.0500 & 0.0003 & 0.356 & 0.005 & 0.0517 & 0.0006 & 28 & 6 & 314 & 2 & 274 & 26 \\
\hline 16.1 & LtUZCo & 6 & 127 & 47 & 0.37 & 2 & 0.000408 & 0.000157 & 0.1013 & 0.0084 & 0.0138 & 0.0013 & 0.0499 & 0.0021 & 0.323 & 0.033 & 0.0470 & 0.0041 & 276 & 26 & 314 & 13 & 48 & 197 \\
\hline 27.1 & LtCZCo & 3 & 60 & 49 & 0.81 & 0 & 0.000192 & 0.000146 & 0.2560 & 0.0113 & 0.0156 & 0.0008 & 0.0495 & 0.0011 & 0.350 & 0.024 & 0.0513 & 0.0032 & 312 & 16 & 312 & 7 & 253 & 151 \\
\hline 33.1 & MedCZCo & 28 & 530 & 324 & 0.61 & 6 & 0.000248 & 0.000100 & 0.1915 & 0.0045 & 0.0155 & 0.0004 & 0.0493 & 0.0004 & 0.347 & 0.014 & 0.0511 & 0.0019 & 310 & 8 & 310 & 3 & 243 & 89 \\
\hline 20.1 & MedSZ?Co & 21 & 464 & 31 & 0.068 & 1 & 0.000061 & 0.000059 & 0.0209 & 0.0024 & 0.0150 & 0.0018 & 0.0488 & 0.0005 & 0.355 & 0.010 & 0.0528 & 0.0014 & 301 & 35 & 307 & 3 & 321 & 59 \\
\hline 2.2 & DrkBCo & 70 & 1358 & 794 & 0.59 & 1 & 0.000014 & 0.000006 & 0.1835 & 0.0021 & 0.0153 & 0.0002 & 0.0487 & 0.0002 & 0.354 & 0.005 & 0.0527 & 0.0007 & 306 & 4 & 306 & 1 & 317 & 28 \\
\hline 30.1 & MedCZCo & 11 & 187 & 187 & 1.00 & 0 & 0.000020 & 0.000020 & 0.3224 & 0.0054 & 0.0157 & 0.0003 & 0.0487 & 0.0005 & 0.355 & 0.013 & 0.0528 & 0.0019 & 316 & 6 & 306 & 3 & 321 & 82 \\
\hline 18.1 & MedSZCo & 38 & 848 & 13 & 0.016 & 1 & 0.000014 & 0.000011 & 0.0053 & 0.0005 & 0.0164 & 0.0017 & 0.0487 & 0.0003 & 0.354 & 0.005 & 0.0528 & 0.0006 & 330 & 34 & 306 & 2 & 319 & 27 \\
\hline 32.1 & $\mathrm{LtBCO}$ & 11 & 225 & 75 & 0.33 & 3 & 0.000344 & 0.000151 & 0.0995 & 0.0065 & 0.0145 & 0.0010 & 0.0485 & 0.0005 & 0.322 & 0.018 & 0.0481 & 0.0025 & 29 & 19 & 306 & 3 & 106 & 120 \\
\hline 13.1 & MedCZ?Co & 18 & 378 & 152 & 0.40 & 0 & 0.000024 & 0.000019 & 0.1263 & 0.0027 & 0.0152 & 0.0004 & 0.0483 & 0.0004 & 0.345 & 0.007 & 0.0518 & 0.0010 & 304 & 7 & 304 & 2 & 276 & 43 \\
\hline 15.1 & LtUZCo & 8 & 157 & 47 & 0.30 & 0 & 0.000020 & 0.000020 & 0.1062 & 0.0038 & 0.0170 & 0.0007 & 0.0479 & 0.0009 & 0.356 & 0.019 & 0.0539 & 0.0026 & 34 & 14 & 302 & 5 & 366 & 113 \\
\hline 6.2 & LtBCo & 6 & 129 & 46 & 0.36 & 1 & 0.000211 & 0.000131 & 0.1080 & 0.0079 & 0.0143 & 0.0011 & 0.0479 & 0.0007 & 0.323 & 0.017 & 0.0488 & 0.0024 & 287 & 21 & 302 & 4 & 140 & 120 \\
\hline 3.1 & BlkWZOg & 201 & 4419 & 9 & 0.002 & 2 & 0.000009 & 0.000003 & 0.0006 & 0.0001 & 0.0134 & 0.0033 & 0.0487 & 0.0002 & 0.352 & 0.002 & 0.0527 & 0.0002 & 268 & 66 & 305 & 1 & 302 & 10 \\
\hline 1.1 & BlkWZOg & 188 & 4085 & 15 & 0.004 & 1 & 0.000007 & 0.000003 & 0.0009 & 0.0001 & 0.0 & 0.0017 & 0.0493 & 0.0001 & 0.3 & 0.002 & 0.0530 & 0.0002 & 258 & 34 & 310 & 1 & 330 & 9 \\
\hline 14.2 & BlkWZOg & 112 & 2563 & 111 & 0.043 & 10 & 0.000096 & 0.000026 & 0.0022 & 0.0011 & 0.0024 & 0.0012 & 0.0482 & 0.0001 & 0.348 & 0.004 & 0.0523 & 0.0005 & 49 & 24 & 304 & 1 & 300 & 23 \\
\hline 2.1 & DrkWZOg & 83 & 2090 & 140 & 0.067 & 106 & 0.001320 & 0.000075 & 0.0019 & 0.0030 & 0.0013 & 0.0020 & 0.0438 & 0.0002 & 0.311 & 0.008 & 0.0515 & 0.0013 & 25 & 40 & 276 & 1 & 264 & 57 \\
\hline 11.1 & BlkWZOg & 53 & 1428 & 140 & 0.098 & 13 & 0.000262 & 0.000042 & 0.0088 & 0.0017 & 0.0037 & 0.0007 & 0.0406 & 0.0002 & 0.291 & 0.005 & 0.0520 & 0.0008 & 74 & 14 & 257 & 1 & 284 & 35 \\
\hline 4.1 & DrkSZOg & 64 & 1412 & 44 & 0.031 & 2 & 0.000030 & 0.000011 & 0.0087 & 0.0005 & 0.0138 & 0.0008 & 0.0494 & 0.0002 & 0.361 & 0.004 & 0.0529 & 0.0005 & 276 & 16 & 311 & 1 & 326 & 23 \\
\hline 10.1 & DrkSZOg & 62 & 1396 & 83 & 0.060 & 39 & & 0.000063 & 0.0064 & 0.0025 & 0.0052 & 0.0020 & 0.0485 & 0.0003 & 0.349 & 0.008 & 0.0521 & 0.0011 & 104 & 41 & 306 & 2 & 292 & 47 \\
\hline 6.1 & MedSZOg & 51 & 1133 & 23 & 0.020 & 1 & 0.000014 & 0.000014 & 0.0068 & 0.0007 & 0.0168 & 0.0016 & 0.0497 & 0.0003 & 0.364 & 0.005 & 0.0531 & 0.0006 & 337 & 32 & 312 & 2 & 333 & 25 \\
\hline 16.2 & DrkSZOg & 45 & 1086 & 48 & 0.044 & 17 & 0.000403 & 0.000069 & 0.0102 & 0.0028 & 0.0105 & 0.0029 & 0.0454 & 0.0003 & 0.322 & 0.009 & 0.0514 & 0.0013 & 212 & 58 & 286 & 2 & 260 & 57 \\
\hline 5.1 & MedsZC & 43 & 919 & 51 & 0.0 & 99 & 0. & 0.0 & 0.0232 & 0.0073 & 0.0 & 0.0067 & 0.0505 & 0.0004 & 0.397 & 0.024 & 0.0570 & 0.0034 & 423 & 132 & 317 & 3 & 491 & 136 \\
\hline 15.2 & DrkWZOg & 35 & 803 & 9 & 0.012 & 1 & 0.000022 & 0.000016 & 0.0038 & 0.0007 & 0.0155 & 0.0027 & 0.0477 & 0.0004 & 0.341 & 0.006 & 0.0519 & 0.0008 & 311 & 54 & 300 & 2 & 280 & 33 \\
\hline 9.1 & MedWZog & 32 & 694 & 42 & 0.061 & 2 & 0.000059 & 0.000034 & 0.0182 & 0.0014 & 0.0151 & 0.0012 & 0.0505 & 0.0005 & 0.362 & 0.007 & 0.0520 & 0.0009 & 303 & 24 & 318 & 3 & 285 & 38 \\
\hline 7.1 & MedSZOg & 21 & 470 & 53 & 0.11 & 6 & 0.000310 & 0.000069 & 0.0185 & 0.0030 & 0.0077 & 0.0013 & 0.0474 & 0.0005 & 0.347 & 0.010 & 0.0530 & 0.0014 & 156 & 25 & 299 & 3 & 329 & 62 \\
\hline
\end{tabular}

Zircon type codes: -

Cathodoluminescence: Lt - light, Med - medium, Drk - dark, Blk - none.

Zoning: SZ - strong, WZ - weak, CZ - concentric, B - banded, UZ - unzoned

Location: $\mathrm{Co}$ - core, $\mathrm{Og}$ - overgrowth.

?atiogenc, corrected 


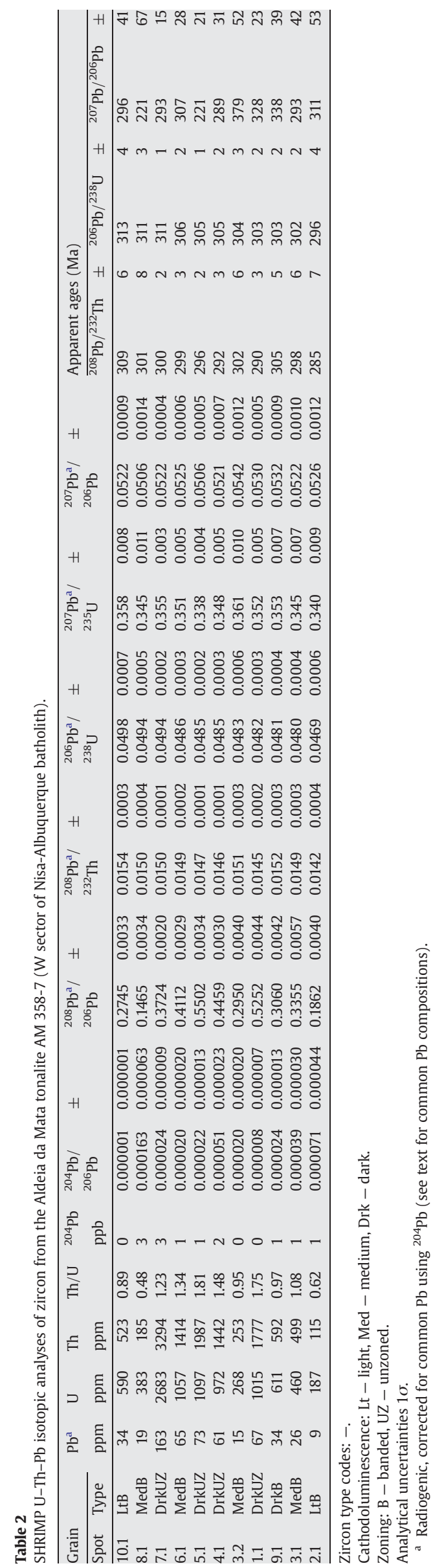

usually consists of just the thin, simply zoned layer (Fig. 2, grain 12). Some outer layers have such weak CL that no zoning is visible.

\subsubsection{Aldeia da Mata tonalite (AM 358-7)}

Zircon in the tonalite occurs as large (up to $300 \mu \mathrm{m}$ ), clear, glassy, weakly coloured, blocky grains with very few inclusions and no visible zoning. Many grains are highly fractured and few preserve obvious crystal faces, probably in part due to fragmentation during mineral separation. CL imaging shows that most of the crystals have broad banded zoning with moderate to strong CL contrast (Fig. 3, grains 6, 9), as is common in zircon from mafic igneous rocks (Hoskin, 2000). Some grains with very weak CL show little or no zoning (Fig. 3, grain 7 ). None of the grains has strong internal textural discontinuities that would indicate the presence of an inherited core.

\section{4. $\mathrm{U}-\mathrm{Th}-\mathrm{Pb}$ analytical results}

\subsubsection{Nisa monzogranite ( $N 346-10)$}

The aim of the zircon dating was twofold; to determine the igneous crystallization age of the monzogranite and, from the inherited zircon, to characterize its protolith. The results are listed in Table 1 and plotted in Fig. 4. Initially the analyses were focused on the outermost, very weakly luminescent overgrowths. These were found to have high to very high-U contents (694-4419 ppm) and low to very low Th/U (0.10-0.002), common features of zircon crystallized from a peraluminous melt (Williams, 2001). The ${ }^{206} \mathrm{~Pb} /{ }^{238} \mathrm{U}$ ages were consistently about $300 \mathrm{Ma}$, but dispersed much more than expected from the analytical uncertainties, indicative in some cases of major radiogenic $\mathrm{Pb}$ loss. Subsequent analyses were directed at other parts of the grains, including texturally obvious cores, broad overgrowths with medium $\mathrm{CL}$, and grains in which the distinction between core and overgrowth was not clear-cut. Many of these analyses also yielded ${ }^{206} \mathrm{~Pb} /{ }^{238} \mathrm{U}$ ages of about $300 \mathrm{Ma}$, again dispersed more than expected from the analytical uncertainties. Twelve of the 'cores' proved to be much older (c. 2.56-0.51 Ga; Fig. 4A).

The zircon yielding ${ }^{206} \mathrm{~Pb} /{ }^{238} \mathrm{U}$ ages of about $300 \mathrm{Ma}$ (Fig. 4B) can be broadly classified into three texturally and chemically distinct types: 1) high-U, low-Th/U outermost overgrowths (Fig. 2, e.g. grain 1); 2) moderate $U$ and $\mathrm{Th} / \mathrm{U}$ zircon with concentric zoning occurring both as inner overgrowths and whole grains (Fig. 2, e.g. grain 13) and; 3 ) texturally discordant cores (Fig. 2, e.g. grains 6, 15, 30). It was not possible to identify in advance on any textural basis which cores were 'young' or 'old' (Fig. 2-see pairs of grains 5/6, and 29/30).

The twelve analyses of low-Th/U outer overgrowths have a very wide range in ${ }^{206} \mathrm{~Pb} /{ }^{238} \mathrm{U}(\mathrm{MSWD}=160$; Fig. 4B). The three lowest analyses $(2.1,11.1,16.2$, Table 1$)$ all have relatively high common $\mathrm{Pb}$ contents, consistent with common $\mathrm{Pb}$ gain and radiogenic $\mathrm{Pb}$ loss. Even when these are omitted the scatter remains high $(M S W D=10)$ because the individual determinations are relatively precise due to the zircon's high radiogenic $\mathrm{Pb}$ contents, so a small range in ${ }^{206} \mathrm{~Pb} /{ }^{238} \mathrm{U}$ is detected as being significant. The scatter cannot be reduced significantly by the omission of any other individual analysis; the distribution of compositions is bimodal, not skewed. Five analyses are scattered about $311 \mathrm{Ma}$, and four are clustered about $304 \mathrm{Ma}$ (Fig. 4B). Analyses with high common $\mathrm{Pb}$ are not restricted to the lower group, and omission of all the lower ${ }^{206} \mathrm{~Pb} /{ }^{238} \mathrm{U}$ analyses cannot be independently justified. Pooling the nine analyses gives a weighted mean ${ }^{206} \mathrm{~Pb} /{ }^{238} \mathrm{U}$ age of $307.4 \pm 4.0 \mathrm{Ma}$, the large uncertainty reflecting the excess scatter (Fig. $4 \mathrm{~B}$ ).

The effects of isotopic disturbance are much more evident in the ${ }^{208} \mathrm{~Pb} /{ }^{232} \mathrm{Th}$ analyses. Some of the spots with relatively high common $\mathrm{Pb}$ contents (e.g. 2.1, 11.1, Table 1 ) have very low radiogenic ${ }^{208} \mathrm{~Pb} /$ ${ }^{232} \mathrm{Th}$, indicative of severe loss of radiogenic ${ }^{208} \mathrm{~Pb}$ in preference to ${ }^{206} \mathrm{~Pb}$. In contrast, spot 5.1, also with high common $\mathrm{Pb}$, has an excess of ${ }^{208} \mathrm{~Pb}$. This behaviour is consistent with the common observation that the $\mathrm{Pb}-\mathrm{Th}$ isotopic system in zircon is much more susceptible to 
A

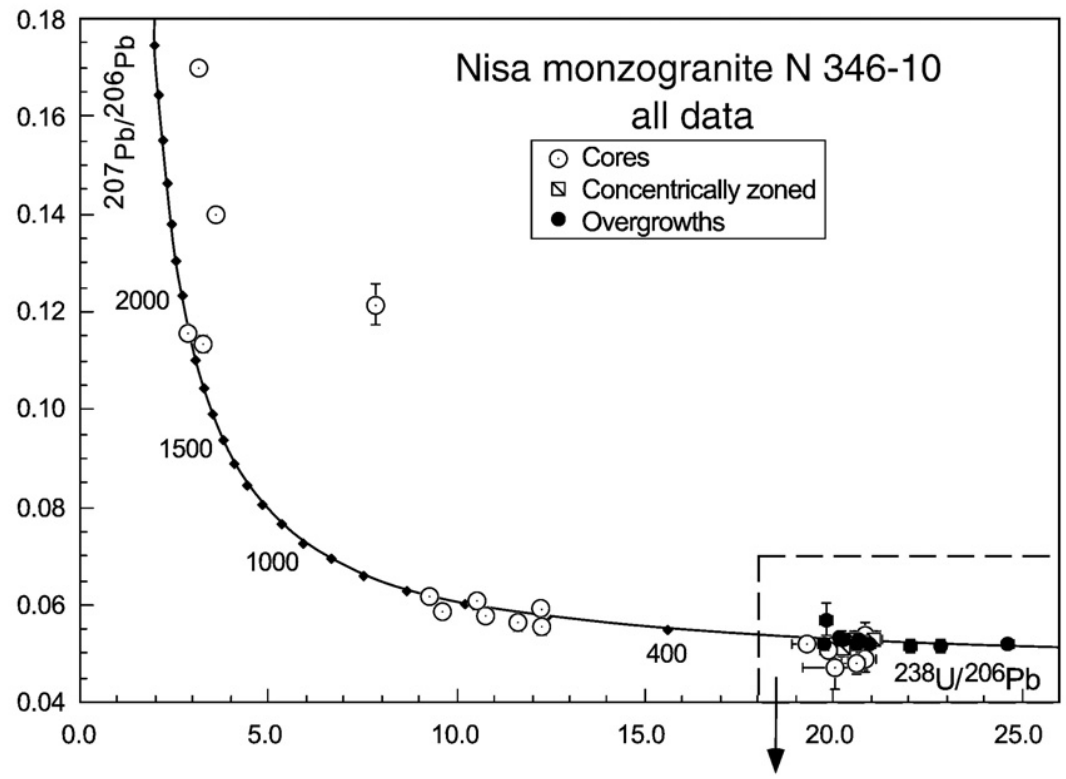

B

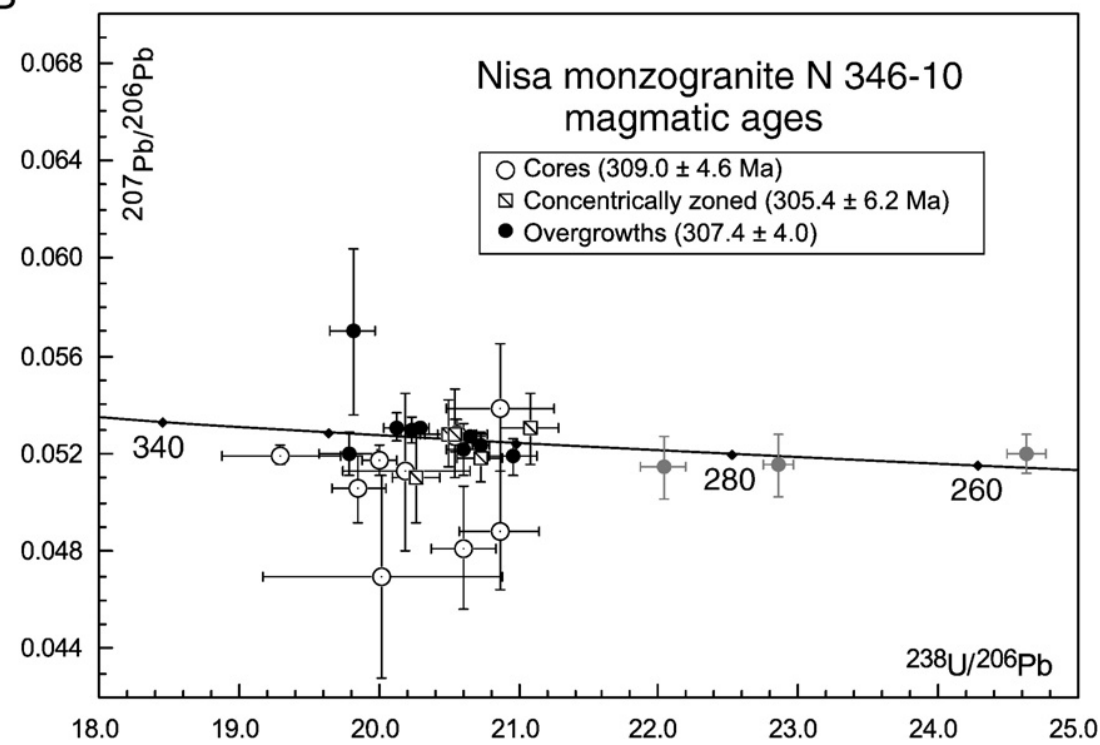

Fig. 4. Tera-Wasserburg concordia diagram of SHRIMP U-Pb isotopic analyses of zircon from the Nisa monzogranite (sample N 346-10). A. All data; B. younger zircon c. 300 Ma (igneous ages). Gray symbols: analyses not included in the age calculation (see text).

disturbance than the $\mathrm{Pb}-\mathrm{U}$ system, a feature borne out by many of the overgrowth $\mathrm{Pb} / \mathrm{Th}$ ages being significantly lower than the $\mathrm{Pb} / \mathrm{U}$ ages.

The 'young' zircon with concentric zoning has much lower U (187$530 \mathrm{ppm})$ and mostly higher $\mathrm{Th} / \mathrm{U}(0.07-1.0)$ than the overgrowths (Table 1). The five areas analysed have a range in ${ }^{206} \mathrm{~Pb} /{ }^{238} \mathrm{U}$ only slightly larger than that expected from the analytical uncertainties $(\mathrm{MSWD}=2.8)$. Pooling the analyses yields a weighted mean ${ }^{206} \mathrm{~Pb} /$ ${ }^{238} \mathrm{U}$ age of $305.4 \pm 6.2 \mathrm{Ma}$, the large uncertainty reflecting the scatter (Fig. 4B).

The nine analyses of 'young' cores are also more dispersed in ${ }^{206} \mathrm{~Pb} /{ }^{238} \mathrm{U}$ than expected from the analytical uncertainties $(M S W D=3.7)$, but none has high common $\mathrm{Pb}$ and there are no obvious low or high outliers. Pooling all analyses yields a weighted mean ${ }^{206} \mathrm{~Pb} /{ }^{238} \mathrm{U}$ age of $309.0 \pm 4.6 \mathrm{Ma}$, the uncertainty again taking the scatter into account (Fig. 4B). None of these cores shows the extreme loss of radiogenic ${ }^{208} \mathrm{~Pb}$ observed in some of the overgrowths (Table 1) which, given that ${ }^{208} \mathrm{~Pb}$ tends to be more mobile in zircon than ${ }^{206} \mathrm{~Pb}$, indicates that they are more likely than the overgrowths to approach closed isotopic systems for ${ }^{206} \mathrm{~Pb} /{ }^{238} \mathrm{U}$.

The twelve older cores have a wide range in age and composition (Fig. 4A and Table 1). $\mathrm{U}$ contents are moderate to high (114$1453 \mathrm{ppm})$ and $\mathrm{Th} / \mathrm{U}$ is moderate $(0.10-1.2)$. The cores fall broadly into two age groups, Neoproterozoic to Cambrian (c. 660-505 Ma), and Paleoproterozoic and older (2.56-1.85 Ga). There are too few analyses to detect clustering within these groups. The analyses of Neoproterozoic cores are nearly concordant, but with two exceptions, those of the older cores are discordant, making accurate estimation of the original ages difficult (Fig. 4A).

\subsubsection{Aldeia da Mata tonalite (AM 358-7)}

To determine the age of the tonalite, eleven areas, mainly near the edges of ten representative zircon grains, were analysed. The data are listed in Table 2 and plotted in Figs. 5 and 6B. The zircon has a wide range of $U$ (187-2683 ppm) and Th (115-3294 ppm) contents, and moderate to high $\mathrm{Th} / \mathrm{U}(0.48-1.81)$ (Table 2$)$. The analysed areas have 


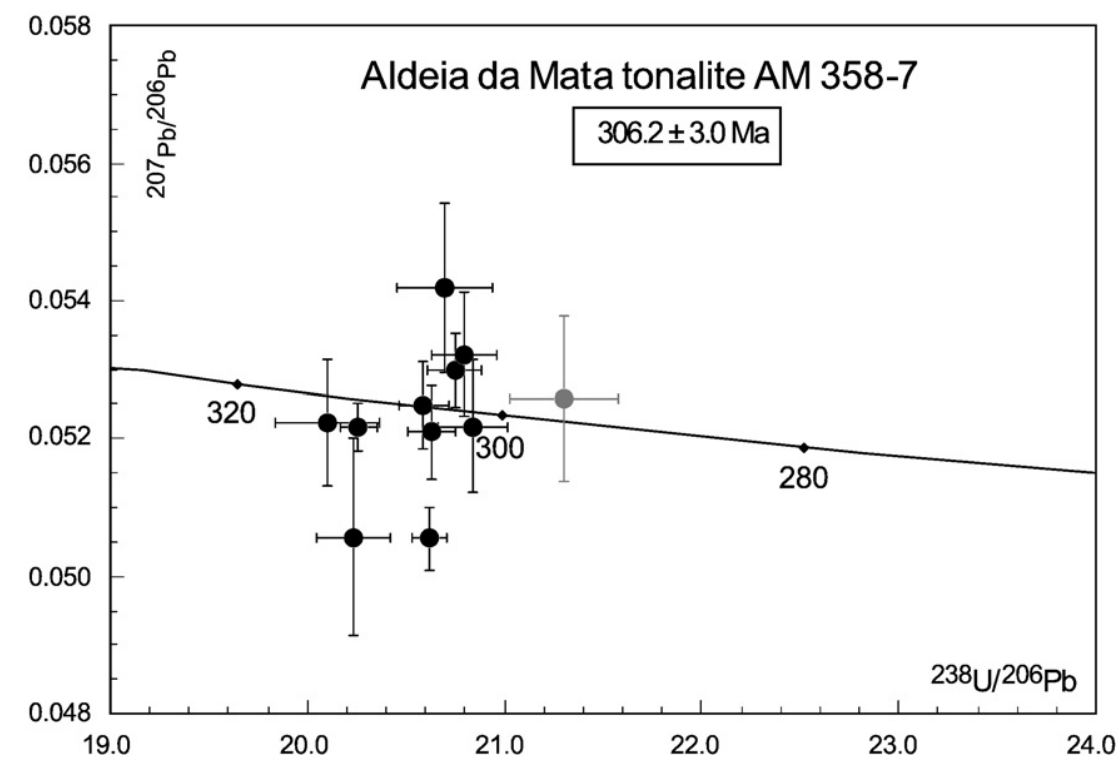

Fig. 5. Tera-Wasserburg concordia diagram of SHRIMP U-Pb isotopic analyses of zircon from the Aldeia da Mata tonalite (sample AM 358-7). Gray symbol: analysis not included in the age calculation (see text).

a limited range of near-concordant isotopic compositions, but the ${ }^{206} \mathrm{~Pb} /{ }^{238} \mathrm{U}$ apparent ages are dispersed more than expected from the analytical uncertainties (313-296 Ma). Omitting the analysis with lowest ${ }^{206} \mathrm{~Pb} /{ }^{238} \mathrm{U}(2.1)$, assuming radiogenic $\mathrm{Pb}$ loss, reduces the scatter but does not eliminate it $(\mathrm{MSWD}=2.4)$. No obvious outlier remains, however. Pooling the ten remaining analyses yields a weighted mean ${ }^{206} \mathrm{~Pb} /{ }^{238} \mathrm{U}$ age of $306.2 \pm 3.0 \mathrm{Ma}$, the uncertainty reflecting the excess scatter.

Omission of only two analyses $(1.1,2.1)$ eliminates all significant scatter in the ${ }^{208} \mathrm{~Pb} /{ }^{232} \mathrm{Th}$ measurements, giving a weighted mean age of $299.0 \pm 3.4 \mathrm{Ma}$, marginally less than the weighted mean ${ }^{206} \mathrm{~Pb} /{ }^{238} \mathrm{U}$ age, again consistent with the observation that the $\mathrm{Pb}-\mathrm{Th}$ system in zircon is more susceptible to external influences than the $\mathrm{Pb}-\mathrm{U}$ system.

\subsection{Interpretation and discussion of the $U-T h-P b$ results}

\subsubsection{Younger zircon from the Nisa monzogranite (N 346-10)}

Despite the contrasts in composition and textural setting of the three 'young' zircon types (high-U, low-Th/U outermost overgrowths; moderate $\mathrm{U}$ and $\mathrm{Th} / \mathrm{U}$ with concentric zoning; and 'young' cores), all have mean ${ }^{206} \mathrm{~Pb} /{ }^{238} \mathrm{U}$ ages that are mutually indistinguishable, $307.4 \pm 4.0,305.4 \pm 6.2$ and $309.0 \pm 4.6 \mathrm{Ma}$, respectively (Fig. 4B). The texturally distinct cores must represent an early stage of growth. Either the protolith of the monzogranite contained some zircon only a little older than the monzogranite itself, or zircon grew in the monzogranite in two stages, separated by a period of zircon undersaturation. The former seems unlikely in the regional geological context. The latter would be possible if the magma was reheated soon after cooling to the point of zircon saturation. This is consistent with the dissolution features evident in some of both the older and younger cores (Fig. 2-see pair of grains 29/30). Alternatively, the dissolution features observed possibly record a change in the melt composition related to an event such as magma mixing (Hoskin and Schaltegger, 2003).

The contrast in $U$ and Th concentrations between the concentrically zoned zircon and the late overgrowths is very marked. The latter have much higher $U$ and lower Th/U than the former. This implies that the zircon crystallized in different chemical environments, the first like that found in intermediate to felsic metaluminous magmas and the second like that found in peraluminous magmas from which a Th-rich mineral phase such as monazite was also crystallizing. The monzogranite is both peraluminous and monazitebearing, so the late overgrowths, which are found on virtually all zircon grains, can be interpreted as the zircon precipitated from the melt phase of the magma. One possibility is that the chemical contrast between the late overgrowths and other zones of the 'young' zircon reflects the magma becoming monazite saturated at a late stage as it fractionated. Another possibility is that the two types of zircon crystallized from different magmas.

Summarizing, the three generations of 'young' zircon indicate a complex evolution of the Nisa-Albuquerque batholith and seem to result from significant thermal and chemical changes that took place during the crystallization of the batholith during a time period that is too short for us to resolve, between $309.0 \pm 4.6 \mathrm{Ma}$ (mean age of earlier cores) and $307.4 \pm 4.0 \mathrm{Ma}$ (mean age of late overgrowths). Although having relatively large analytical uncertainties, these newlymeasured ages are more internally consistent than those previously obtained by $\mathrm{Rb}-\mathrm{Sr}$ and $\mathrm{K}-\mathrm{Ar}$ methods ( $312 \pm 9$ to $286 \pm 4 \mathrm{Ma}$, see Section 2).

\subsubsection{Aldeia da Mata tonalite (AM 358-7)}

Considering the analytical uncertainties, the mean age obtained for zircons from the Aldeia da Mata tonalite, 306.2 \pm 3.0 Ma (Fig. 5), is indistinguishable from the mean ages of the three generations of 'young' zircon from the Nisa monzogranite, $307.4 \pm 4.0 \mathrm{Ma}, 305.4 \pm$ 6.2 Ma and 309.0 $\pm 4.6 \mathrm{Ma}$ (Fig. 4B), consistent with the emplacement of both granitoids within a very short period of time. Petrographic features and Anisotropy of the Magnetic Susceptibility (ASM) data, however, favour intrusion of the tonalite after the monzogranite (Solá et al., 1998a). The 306.2 \pm 3.0 Ma zircon crystallization age of the tonalite possibly indicates late injection of the tonalite magma into a partially crystallized host monzogranite mass. This is consistent with the contact features observed in the field and the emplacement sequence of the granitic facies proposed by González Menéndez and Azor (2006).

Despite the approximately coeval emplacement of the external monzogranite and core tonalite, their contrasting zircon growth textures and $U$ and Th contents indicate contrasting sources for the two magmas. Zircon grains from the tonalite have much simpler, single stage growth textures than those from the monzogranite, and no inherited cores were found, as is common in zircon from relatively unevolved metaluminous igneous rocks. This feature suggests zircon crystallization from a largely or completely molten magma in which 
Table 3

SHRIMP oxygen isotopic analyses of zircon from the Nisa-Albuquerque batholith.

\begin{tabular}{|c|c|c|c|c|c|}
\hline Grain & ${ }^{206} \mathrm{~Pb} /{ }^{238} \mathrm{U}$ & s.e. & $\mathrm{Th} / \mathrm{U}$ & $\delta^{18} \mathrm{O}$ & 2 s.e. \\
\hline Spot & & & & & \\
\hline \multicolumn{6}{|c|}{ Nisa monzogranite (N 346-10) } \\
\hline \multicolumn{6}{|c|}{ High-U overgrowths } \\
\hline 1.1 & 310 & 1 & 0.004 & 9.8 & 0.2 \\
\hline 2.1 & 276 & 1 & 0.067 & 9.4 & 0.2 \\
\hline 4.1 & 311 & 1 & 0.031 & 10.0 & 0.2 \\
\hline 6.1 & 312 & 2 & 0.020 & 9.4 & 0.2 \\
\hline 10.1 & 306 & 2 & 0.060 & 9.3 & 0.1 \\
\hline 14.2 & 304 & 1 & 0.043 & 9.2 & 0.1 \\
\hline \multicolumn{6}{|c|}{ Medium-U overgrowths } \\
\hline 5.1 & 317 & 3 & 0.055 & 9.3 & 0.2 \\
\hline 7.1 & 299 & 3 & 0.11 & 9.9 & 0.2 \\
\hline 9.1 & 318 & 3 & 0.061 & 9.4 & 0.2 \\
\hline \multicolumn{6}{|c|}{ Low-Th/U Variscan cores } \\
\hline 18.1 & 306 & 2 & 0.016 & 10.0 & 0.2 \\
\hline 20.1 & 307 & 3 & 0.068 & 9.4 & 0.3 \\
\hline 25.1 & 326 & 7 & 0.020 & 9.5 & 0.1 \\
\hline \multicolumn{6}{|c|}{ High-Th/U Variscan cores } \\
\hline 2.2 & 306 & 1 & 0.59 & 7.4 & 0.2 \\
\hline 13.1 & 304 & 2 & 0.40 & 8.1 & 0.2 \\
\hline 16.1 & 314 & 13 & 0.37 & 9.7 & 0.1 \\
\hline 27.1 & 312 & 7 & 0.81 & 8.2 & 0.2 \\
\hline 28.1 & 317 & 3 & 0.49 & 8.5 & 0.2 \\
\hline 30.1 & 306 & 3 & 1.00 & 9.5 & 0.1 \\
\hline 32.1 & 306 & 3 & 0.33 & 10.9 & 0.1 \\
\hline 33.1 & 310 & 3 & 0.61 & 6.7 & 0.1 \\
\hline \multicolumn{6}{|c|}{ Older cores < $1 \mathrm{Ga}$} \\
\hline 5.2 & 572 & 5 & 0.87 & 6.3 & 0.2 \\
\hline 7.2 & 506 & 4 & 0.10 & 4.4 & 0.1 \\
\hline 8.2 & 531 & 5 & 0.24 & 8.4 & 0.2 \\
\hline 10.2 & 506 & 7 & 0.17 & 10.0 & 0.2 \\
\hline 24.1 & 636 & 11 & 0.42 & 6.9 & 0.1 \\
\hline 29.1 & 585 & 6 & 0.47 & 8.0 & 0.1 \\
\hline 31.1 & 661 & 3 & 0.90 & 7.7 & 0.1 \\
\hline \multicolumn{6}{|c|}{ Older cores > $1 \mathrm{Ga}$} \\
\hline 14.1 & $1977^{\mathrm{a}}$ & 63 & 1.20 & 6.0 & 0.2 \\
\hline 23.1 & $1892^{\mathrm{a}}$ & 21 & 0.59 & 5.5 & 0.2 \\
\hline 26.1 & $2556^{a}$ & 14 & 0.65 & 4.7 & 0.1 \\
\hline \multicolumn{6}{|c|}{ Aldeia da Mata tonalite (AM 358-7) } \\
\hline 1.1 & 303 & 2 & 1.75 & 7.4 & 0.2 \\
\hline 2.1 & 296 & 4 & 0.62 & 7.4 & 0.1 \\
\hline 3.1 & 302 & 2 & 1.08 & 7.3 & 0.2 \\
\hline 4.1 & 305 & 2 & 1.48 & 7.6 & 0.2 \\
\hline 5.1 & 305 & 1 & 1.81 & 7.5 & 0.1 \\
\hline 6.1 & 306 & 2 & 1.34 & 7.9 & 0.2 \\
\hline 8.1 & 311 & 3 & 0.48 & 7.2 & 0.1 \\
\hline 9.1 & 303 & 2 & 0.97 & 7.0 & 0.1 \\
\hline
\end{tabular}

crystals of zircon initially were not present because the melt was zircon undersaturated (i.e. the tonalite corresponds to hightemperature I-type granite, Chappell et al., 1998). Furthermore, the tonalite zircon Th/U ratio is generally $>1$, much higher than that in the late melt-precipitated zircon from the monzogranite (Table 2), indicative of a different magma source.

\subsection{Zircon oxygen isotopic compositions}

\subsubsection{Nisa monzogranite ( $N$ 346-10)}

The zircon from the Nisa monzogranite has a very wide range of oxygen isotopic compositions (Table 3 and Fig. 6A) that are closely related to the zircon age and Th/U. All the 'young' zircon with low $\mathrm{Th} / \mathrm{U}(\leq 0.1)$, both cores and overgrowths, has uniformly heavy oxygen, with an average $\delta^{18} \mathrm{O}_{\mathrm{zrc}}$ of $9.5 \pm 0.2 \%$ 。 $(n=12)$. The 'young' zircon cores with $\mathrm{Th} / \mathrm{U}>0.1$, in contrast, have a wide range of composition $\left(\delta^{18} \mathrm{O}_{\mathrm{Zrc}}=6.7-10.9 \%\right.$ ) and on average their oxygen is lighter $(8.7 \%, n=8)$.

The old zircon cores have an even wider range of oxygen isotopic composition $\left(\delta^{18} \mathrm{O}_{\mathrm{Zrc}}=4.4-10.0 \%\right.$ ), and are on average lighter again, especially the cores older than $1.0 \mathrm{Ga}$, two of which have compositions in the range of mantle zircon; $\delta^{18} \mathrm{O}_{\mathrm{Zrc}}=5.5$ and $6.0 \%$ (e.g., Valley, 2003). The two high-U cores that are fractured and altered (analyses 7.2 and 26.1, Table 3$)$ have very light oxygen $\left(\delta^{18} \mathrm{O}_{\mathrm{Zrc}}=4.4\right.$ and $4.7 \%$ respectively), probably indicating oxygen exchange with meteoric water (e.g., Valley et al., 1994).

\subsubsection{Aldeia da Mata tonalite (AM 358-7)}

In contrast to the monzogranite, the oxygen isotopic composition of the tonalite zircon is very uniform. The analyses scatter little more than those of the isotopically homogeneous Temora standard (Table 3 and Fig. 6B). The average $\delta^{18} \mathrm{O}_{\mathrm{Zrc}}$ is $7.4 \pm 0.3 \%$ 。 $(n=8)$, about $2 \%$ 。 lighter than the oxygen in the melt-precipitated zircon from the monzogranite.

\subsection{Source rock constraints}

\subsubsection{Nisa monzogranite (N 346-10)}

The oxygen isotope fractionation between a granitoid magma and crystallizing zircon is $\sim 1$ to $2 \%$, depending on the magma $\mathrm{SiO}_{2}$ content (Lackey et al., 2008), so knowing the oxygen isotopic composition of zircon and the $\mathrm{SiO}_{2}$ content of the magma, it is possible to estimate the isotopic composition of the magma from which it crystallized. The differences in oxygen isotopic composition between the zircon overgrowths and 'young' cores in the Nisa monzogranite are inconsistent with the zircon having crystallized from a single evolving magma (Table 3 and Fig. 6A). While the overgrowths, whether high or
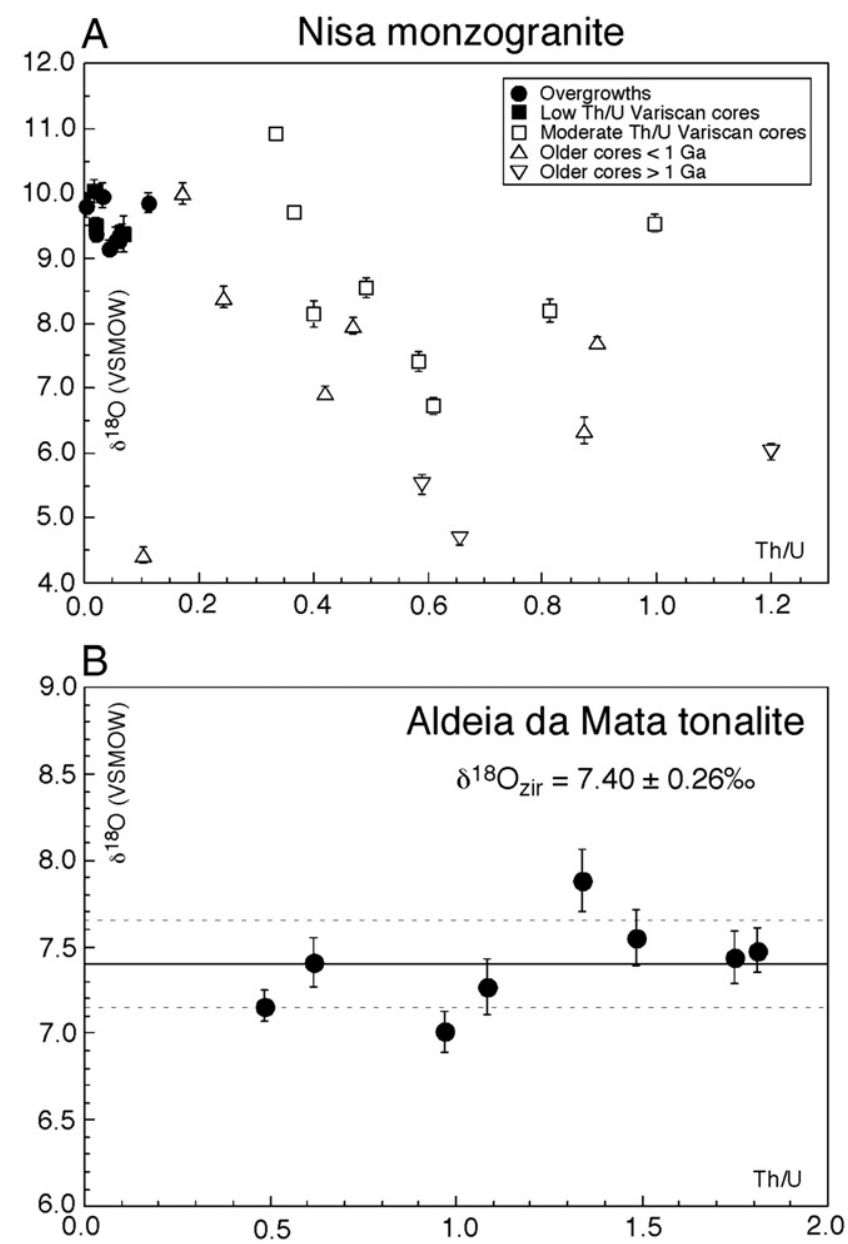

Fig. 6. Oxygen isotopic compositions of zircon from the Nisa-Albuquerque batholith (measured on spots previously analysed for U-Pb geochronology) vs. Th/U. A) Nisa monzogranite (sample N 346-10) with discrimination of texturally and chemically distinct types; B) Aldeia da Mata tonalite (sample AM 358-7). 
low uranium, CL dark unzoned or medium CL with oscillatory zoning, probably crystallized from the same S-type magma, the texturally distinct cores record a more complex history. Those with low Th/U that have heavy oxygen, just like the overgrowths, could have crystallized from the same S-type magma as the overgrowths. With the exception of grains 16.1, 30.1 and 32.1 (Table 3), the remaining higher Th/U cores are lighter $\left(\delta^{18} \mathrm{O}_{\mathrm{Zrc}}=6.7-8.5 \%\right.$ ) and must have crystallized from magma with a different crustal source that consisted predominantly of isotopically lighter igneous rock.

The zircon oxygen isotopic compositions, as well as the zircon morphology and ages, are consistent with partial melting of two independent sources and subsequent mixing of the respective magmas. The older magma was probably metaluminous, possibly with a small component derived from partial melting of sedimentary rocks. The heterogeneity in the oxygen isotopic compositions of the 'young' zircon cores with moderate Th/U might reflect a heterogeneous distribution of that component in the source rocks. The younger magma was peraluminous and contained a larger sedimentary component which contributed to the old zircon cores. The age difference between the two magmas is less than the precision of the zircon age measurements. Partial dissolution of the older zircon prior to the crystallization of the younger zircon indicates that at some stage the older magma or mixed magma was zircon undersaturated. The older magma is unlikely to be the same magma that produced the Aldeia da Mata tonalite; the zircon from the tonalite is more uniform in oxygen isotopic composition and has higher Th/U than the 'young', moderate-Th/U zircon cores in the monzogranite.

During the Variscan regional heating event, partial melting of heterogeneous source rocks probably occurred at different lower to mid-crustal levels. Magmas from two contrasting sources were emplaced into an upper crust magma chamber with some local mixing. This heterogeneous 'melting scenario' is consistent with the occurrence of early deformed (microfracturated) and sometimes corroded plagioclase cores, overgrown by almost undeformed rims that coexist with 'normal' plagioclase crystals, without deformed cores (Solá et al., 1998b). This petrographic feature, like the corroded zircon cores, could also reflect mixing of magmas.

\subsubsection{Aldeia da Mata tonalite (AM 358-7)}

While the monzogranite magma resulted from partial melting of multi-cycle crustal sources (metasedimentary and intermediate meta-igneous rocks), a more mafic source is necessary to produce the tonalitic magma. The oxygen in the tonalite zircon $\left(\delta^{18} \mathrm{O}=7.4 \pm 0.3 \%\right.$ 。 is much heavier than would be found in zircon crystallized from a magma derived directly from the mantle $(\sim 5.3 \pm 0.6 \%$, Valley et al., 1998; Valley, 2003). The tonalite source was possibly a lower-crustal underplate composed of mafic igneous rocks formed from the interaction of a mantle-derived magma with crust.

Several experimental studies suggest that dehydration of amphibolites and metatonalites at mid- to lower-crustal pressures can produce significant volumes of intermediate partial melts, but very high temperatures $\left(\sim 900-1000{ }^{\circ} \mathrm{C}\right)$ are needed (e.g., Wolf and Wyllie, 1994; Rapp and Watson, 1995; and references therein). The zircon from the granitoids of the Nisa-Albuquerque batholith therefore provides strong evidence that the regional heating event during the Variscan orogeny produced partial melts of a variety of rock types at various crustal levels in a single crustal section at virtually the same time.

\section{Inherited zircon: age and source constraints}

The twelve older zircon cores have a wide range of compositions. $\mathrm{U}$ contents are moderate to high (114-1453 ppm) and Th/U is low to moderate $(0.10-1.2)$. With the possible exception of one analysis (7.2), these compositions are similar to those found in zircon from metaluminous intermediate igneous rocks (e.g., Heaman et al., 1990;
Williams, 2001). The high U (1270 ppm) and low Th/U (0.10) of spot 7.2 (Table 1) is more like the composition of zircon precipitated from peraluminous melts of igneous or metamorphic origin (e.g. Williams, 2001).

Although relatively few older cores were analysed, the ages obtained indicate the involvement of a crustal source containing Neoproterozoic-Cambrian (c. 660-505 Ma) and Paleoproterozoic and older (2.56-1.85 Ga) components. The Neoproterozoic-Cambrian zircon cores have a wider range of oxygen isotopic compositions $\left(\delta^{18} \mathrm{O}_{\mathrm{Zrc}}=4.4-10.0 \%\right.$, Table 3$)$. With the exception of spots 7.2 $\left(\delta^{18} \mathrm{O}_{\mathrm{Zrc}}=4.4 \%\right.$ ), which reflects alteration, and $10.2\left(\delta^{18} \mathrm{O}_{\mathrm{Zrc}}=10.0 \%\right.$ o), these compositions are typical to those found in zircon crystallized from a magma with a crustal igneous source (I-type). The two unaltered Paleoproterozoic zircon cores $(14.1,23.1)$ have oxygen isotopic compositions $\left(\delta^{18} \mathrm{O}_{\mathrm{Zrc}}=6.0\right.$ and $5.5 \%$ ) similar to zircon crystallized from magma derived directly from the mantle.

There is a marked absence of cores of Mesoproterozoic age (Fig. 4A), which is significant in a regional geodynamic context. Late Neoproterozoic to Cambrian sediments with a detrital zircon age signature the same as that of the inherited cores are abundant in North Africa (Williams et al., 2002), as well as in SW Iberia (Urra Formation; Solá et al., 2008 and Série Negra; Fernández-Suárez et al., 2002; Pereira et al., 2008b). In contrast, sediments of similar age, but containing a pronounced Mesoproterozoic detrital component, are found in Israel (Avigad et al., 2005) and NW Iberia (e.g., FernándezSuárez et al., 2002), as well as along the proto-Pacific margin of Gondwana (Williams et al., 2002).

Both sediment packages (with or without Mesoproterozoic zircon) originated from the erosion of mountain ranges formed during the final, protracted amalgamation of Gondwana, as marked by the PanAfrican Orogeny, but only the eastern package came from basement rocks that included a Mesoproterozoic component, probably from the Mozambique Belt. The implication of the age pattern from the inherited cores in the Nisa monzogranite is that the sedimentary component in the source of the monzogranite magma from which we suppose those cores to have been derived, was predominantly, and probably entirely, of late Neoproterozoic age or younger (possibly with Ossa-Morena Zone affinity). The North African sediments also contain Paleoproterozoic and Archean detrital zircon, which accounts for the cores of that age in the monzogranite. The cores do not imply the presence of Paleoproterozoic and Archean basement rocks beneath SW Iberia.

\section{Regional implications}

The zircon U-Th-Pb ages for two granitoids from the NisaAlbuquerque batholith reported here (c. 309-306 Ma) are similar to those recently obtained from granitoids in the Los Pedroches batholith (314-304 Ma, ID-TIMS, Carracedo et al., 2008) that lies on the same magmatic trend in south-central Spain. They are also within the age range of 311-306 Ma for the late- $\mathrm{D}_{3}$ Variscan granitoids from the northern domains of the Central Iberian Zone obtained by Dias et al. (1998).

The Nisa-Albuquerque batholith is oriented parallel to Variscan NW-SE-trending structures such as the Coimbra-Córdoba shear zone, which includes sheared migmatites dated at c. $335 \mathrm{Ma}$ (U-Pb dating of metamorphic zircon overgrowths; Ordóñez -Casado, 1998). This is interpreted to be the age of high-grade metamorphism coeval with Visean ductile deformation $\left(D_{2}\right)$ related to Variscan transcurrent movements (transpression; Silva and Pereira, 2004; Pereira et al., 2008a).

The zircon ages measured in the present study indicate an interval of c. 30 m.y. between the migmatization, shearing and uplift related to the transcurrent movements $\left(D_{2}\right)$ along this complex zone of crustal weakness, and the intrusion of the Nisa-Albuquerque granitoids (late$\mathrm{D}_{3}$ ), during transtensional movements (Pereira et al., 1998; Ribeiro, 
2001; Silva and Pereira, 2004). This protracted sequence of tectonothermal events is a feature of this part of the Variscan orogen. A similar sequence of events also occurred over the same period in other areas of the Ossa-Morena Zone, for example in the Évora Massif (Pereira et al., 2007) where, after a first stage of crustal thickening $\left(D_{1}\right.$ dated at c. $371 \mathrm{Ma}$; Sm-Nd in garnet from eclogites; Moita et al., 2005) the Variscan evolution was followed by orogen collapse in relation to transcurrent extensional tectonics, high-grade metamorphism $\left(D_{2}\right.$ dated at c. 345-323 Ma, U-Pb zircon, Chichorro, 2006) coeval with intrusion of granitoids $\left(D_{2}-D_{3}\right.$ dated at c. $320 \mathrm{Ma}$, amphibole $\mathrm{Ar}-\mathrm{Ar}$, Moita, 2008) followed by the emplacement of late Variscan granitoids (late- $\mathrm{D}_{3}$ dated at c. $306 \mathrm{Ma}$; Antunes, 2006).

\section{Conclusions}

The principal conclusions from the present study are as follows:

1) The zircon crystals from the Nisa monzogranite are complexly zoned, with large cores and thin overgrowths. Three texturally and chemically distinct types of syn-magmatic zircon can be distinguished: a) high-U, low-Th/U outermost overgrowths (307.4 \pm $4.0 \mathrm{Ma})$; b) moderate $\mathrm{U}$ and $\mathrm{Th} / \mathrm{U}$ zircon with concentric zoning occurring both as inner overgrowths and whole grains (305.4 $6.2 \mathrm{Ma})$; and c) texturally discordant cores ( $309.0 \pm 4.6 \mathrm{Ma})$. These features indicate a complex evolution for the Nisa-Albuquerque batholith, probably related to significant chemical and thermal changes that occurred during crystallization/emplacement.

2) The main monzogranitic phase of the Nisa-Albuquerque batholith was emplaced between $309.0 \pm 4.6 \mathrm{Ma}$ (mean age of the youngest cores) and $307.4 \pm 4.0 \mathrm{Ma}$ (mean age of overgrowths). Tonalitic magma was injected into the partially crystallized host monzogranite at $306.2 \pm 3.0 \mathrm{Ma}$. These three age measurements are mutually indistinguishable within the analytical uncertainties.

3) Textural unconformities between the zircon cores and zircon with concentric zoning indicate that zircon grew in the monzogranite in two stages, separated by a period of zircon undersaturation, possibly due to magma mixing causing a shift in magma composition and an increase in temperature.

4) There is a very marked contrast in Th/U between the concentrically zoned zircon and the outermost overgrowths, consistent with the magma becoming monazite saturated in the later stages of the zircon crystallization.

5) Contrasts in oxygen isotopic composition between the Variscan zircon with moderate $\mathrm{Th} / \mathrm{U}$ and low Th/U respectively, and the large range in the $\delta^{18} \mathrm{O}$ of the former, preclude the two zircon types having crystallized from the same magma, unless the magma was changing oxygen isotopic composition by assimilation or magma mixing. More likely, the zircon with moderate Th/U crystallized in an I-type magma that incorporated some sediment. That magma was then mixed into a large volume of S-type magma derived from a dominantly sedimentary source.

6) The ages measured on inherited old cores in zircons from the Nisa monzogranite fall broadly into two groups, NeoproterozoicCambrian, nearly concordant ages of 660-505 Ma, and Paleoproterozoic and older, mostly discordant ages of $2.56-1.85 \mathrm{Ga}$. This is the age signature typical of early Paleozoic sediments derived from North Africa, like some sedimentary units in SW Iberia, indicating that such sediment was a major component in the source of the monzogranite magma.

7) Zircon features and compositions indicate different sources for the Nisa monzogranite and Aldeia da Mata tonalite magmas (felsic crustal sources vs. mafic igneous sources). Zircon grains from the Aldeia da Mata tonalite have the banded zoning typical of less evolved igneous rocks and inherited cores were not found. Their $\mathrm{Th} / \mathrm{U}$ is on average much higher than that in the melt-precipitated zircon from the monzogranite, and their $\delta^{18} \mathrm{O}$ is much lower. Their $\delta^{18} \mathrm{O}$ is too high, however, for the magma to have been of direct mantle origin.

\section{Acknowledgements}

This paper corresponds to part of the Ph.D. thesis of A.R. Solá that benefited from the grant SFRH/BD/3142/2000 sponsored by Fundação para a Ciência e a Tecnologia, Portugal, for the analytical work. This research was carried out in the projects of INETI and Geosciences Centre, University of Coimbra. Development of the SHRIMP techniques for oxygen isotopic analysis at the ANU was supported by grant DP0559604 from the Australian Research Council. Stimulating discussions with M. Chichorro and M.F. Pereira helped to improve parts of this paper. Reviews and suggestions by S. Jung (for the Editors), F. Corfu and an anonymous referee were greatly appreciated and led to substantial improvement of the original manuscript.

\section{References}

Antunes, I., 2006. Rochas Granitóides da Zona de Ossa-Morena: Magmatismo, Geodinâmica e Reconstituição Geo-histórica, unpublished PhD dissertation, Universidade de Aveiro, $181 \mathrm{pp}$.

Avigad, D., Sandler, A., Kolodner, K., Stern, R.J., McWilliams, M., Miller, N., Beyth, M., 2005. Mass-production of Cambro-Ordovician quartz-rich sandstone as a consequence of chemical weathering of Pan-African terranes: environmental implications. Earth and Planetary Science Letters 240, 818-826.

Bea, F., Montero, P., Molina, J.F., 1999. Mafic precursors, peraluminous granitoids and late lamprophyres in the Avila batholith: a model for the generation of Variscan batholiths in Iberia. The Journal of Geology 170 (4), 399-419.

Burg, J.P., Iglesias, M., Laurent, P., Matte, Ph., Ribeiro, A., 1981. Variscan intracontinental deformation: the Coimbra-Cordoba shear zone (SW Iberian Peninsula). Tectonophysics 78, 161-177.

Butera, K.M., Williams, I.S., Blevin, P.L., Simpson, C.J., 2001. Zircon U-Pb dating of Early Palaeozoic monzonitic intrusives from the Goonumbla area, New South Wales. Australian Journal of Earth Sciences 48 (3), 457-464.

Campos, A.B.A., Pereira, L.C.G., 1991. A arquitectura e a fracturação no granito de Nisa (Alto Alentejo-Portugal). Memórias e Notícias. Publicações do Museu e Laboratório Mineralógico e Geológico da Universidade de Coimbra, 112 (A), 121-133.

Carracedo, M., Paquette, J.L., Alonso Olazabal, A., Santos Zalduegui, J.F., García de Madinabeitia, S., Tiepolo, M., Gil Ibarguchi, J.I., 2008. U-Pb dating of granodiorite and granite units of the Los Pedroches batholith. Implications for geodynamic models of the southern Central Iberian Zone (Iberian Massif). International Journal of Earth Sciences. doi:10.1007/s00531-008-0317-0.

Chappell, B.W., Bryant, C.J., Wyborn, D., White, A.J.R., Williams, I.S., 1998. High- and lowtemperature I-type granites. Resource Geology 48 (4), 225-235.

Chichorro, M., 2006. A Evolução Tectónica da Zona de Cisalhamento de Montemor-oNovo (Sudoeste da Zona de Ossa Morena - Área de Santiago do Escoural - Cabrela), unpublished PhD dissertation, Universidade de Évora, $521 \mathrm{pp}$.

Cumming, G.L., Richards, J.R., 1975. Ore lead isotope ratios in a continuously changing Earth. Earth and Planetary Science Letters 28, 155-171.

Dias, G., Leterrier, J., Mendes, A., Simões, P.P., Bertrand, J.M., 1998. U-Pb zircon and monazite geochronology of post-collisional Hercynian granitoids from the Centra Iberian Zone (Northern Portugal). Lithos 45, 349-369.

Eguiluz, L., Gil Ibarguchi, J.I., Abalos, B., Apraiz, A., 2000. Superposed Hercynian and Cadomian orogenic cycles in the Ossa-Morena zone and related areas of the Iberian Massif. Geological Society of America Bulletin, 112 9, 1398-1413.

Faria, F.L., Mesquita, L.P., 1962. Jazigos de Urânio da região de Nisa-Castelo de Vide. Boletim da Sociedade Geológica de Portugal 14, 121-139.

Fernández-Suárez, J., Gutiérrez-Alonso, G., Jeffries, T.E., 2002. The importance of alongmargin terrane transport in Northern Gondwana: insights from detrital zircon parentage in Neoproterozoic rocks from Iberia and Brittany. Earth and Planetary Science Letters $204,75-88$

Ferreira, N., Iglésias, M., Noronha, F., Pereira, E., Ribeiro, A., Ribeiro, M.L., 1987. Granitóides da zona Centro-Ibérica e seu enquadramento geodinâmico. In: Bea, F., Carnicero, A Gonzalo, J.C., López-Plaza, M., Rodrígues Alonso, M.D. (Eds.), Geologia de los Granitoids y Rocas Associadas del Macizo Hespérico. Libro Homenagem a L.C.G. Figuerola. Editorial Rueda, Madrid, pp. 37-53.

Geological Map of Portugal (Carta Geológica de Portugal, escala 1:500 000), 1992 Oliveira, J.T., Pereira, E., Ramalho, M., Antunes, M.T., Monteiro, J.H. (Coord.) Serviços Geológicos de Portugal, Lisboa.

Geological Map of Spain (Mapa Geológico de España, 1:2000 000), 2004. In: Vera, J.A (Ed.), Geología de España. SGE-IGME, Madrid, 884 pp.

González Menéndez, L., 2002. Petrología del batolito granítico de Nisa-Alburquerque. Revista Soc Geol España 15, 233-246.

González Menéndez, L., Azor, A., 2006. Estructura interna del batolito granítico de NisaAlburquerque. Geogaceta 40, 131-134.

Heaman, L.M., Bowins, R., Crocket, J., 1990. The chemical composition of igneous zircon studies: implications for geochemical tracer studies. Geochimica et Cosmochimica Acta 54, 1597-1607.

Hoskin, P.W.O., 2000. Patterns of chaos: fractal statistics and the oscillatory chemistry of zircon. Geochimica Cosmochimica Acta 64, 1905-1923. 
Hoskin, P.W.O., Schaltegger, U., 2003. The composition of zircon and igneous and metamorphic petrogenesis. In: Hanchar, J.M., Hoskin, P.W.O. (Eds.), Zircon, Reviews in Mineralogy and Geochemistry, vol. 53. Mineralogical Society of America/ Geochemical Society, Washington, DC, pp. 27-62.

Ickert, R.B., Hiess, J., Williams, I.S., Holden, P., Ireland, T.R., Lanc, P., Schram, N., Foster, J.J., Clement, S.W., 2008. Determining high precision, in situ, oxygen isotope ratios with a SHRIMP II: analyses of MPI-DING silicate-glass reference materials and zircon from contrasting granites. Chemical Geology 257, 114-128.

Lackey, J.S., Valley, J.W., Chen, J.H., Stockli, D.F., 2008. Dynamic magma systems, crustal recycling, and alteration in the central Sierra Nevada Batholith: the oxygen isotope record. Journal of Petrology 49 (7), 1397-1426.

Matte, Ph., 1986. Tectonics and plate tectonics model for the Variscan Belt of Europe. Tectonophysics 126, 329-374

Matte, Ph., 1991. Accretionary history and crustal evolution of the Variscan belt in Western Europe. Tectonophysics 196, 309-337.

Mendes, F., 1967-1968. Contribution à l’ étude géochronologique, par la méthode au strontium, des formations cristallines du Portugal. Boletim do Museu e Laboratório de Mineralogia e Geologia da Faculdade de Ciências de Lisboa 11 (1), 1-155.

Moita, P., 2008. Granitóides no SW da Zona de Ossa-Morena (Montemor-o-Novo - Évora): Petrogénese e Processos Geodinâmicos, unpublished PhD dissertation, Universidade de Évora, $351 \mathrm{pp}$.

Moita, P., Munhá, J., Fonseca, P., Pedro, J., Tassinari, C., Araújo, A., Palácios, T., 2005. Phase equilibria and geochronology of Ossa-Morena eclogites. Actas do XIV Semana de Gequímica/VIII Congresso de geoquímica dos Países de Língua Portuguesa 2, 463-466.

Moreira, A., 1994. Reconhecimento geológico, estrutural, petrográfico e geoquímico dos granitos de Alpalhão, Gáfete e Quareleiros. (Alto Alentejo). Estudos Notas e Trabalhos do Instituto Geológico e Mineiro 36, 103-117.

Neiva, J.M.C., 2003. Portuguese Uranium Deposits and their Genesis. Abstracts from IV Iberian Geochemical Meeting, Coimbra, 27-28.

Neiva, A.M.R., Gomes, M.E.P., 2001. Diferentes tipos de Granitos e seus Processos Petrogenéticos: in Granitos Hercínicos Portugueses. Memórias da Academia de Ciências de Lisboa 39, 53-95.

Neiva, J.M.C., Queiróz, N.M., Faria, F.L., 1952. Géologie et genése dês gisements Portugais d' Apatite. Estudos, Notas e Trabalhos do Serviço de Fomento Mineiro, VIII, 265-278.

Ordóñez -Casado, B., 1998. Geochronological studies of the Pre-Mesozoic basement of the Iberian Massif: the Ossa Morena Zone and Allochthonous complexes within the Central Iberian Zone, Ph D dissertation, ETH (12.940), Zurich.

Penha, M.H., Arribas, A., 1974. Datación geocronológica de algunos granitos uraníferos españoles. Boletín Geológico y Minero 85, 271-273.

Pereira, L.G., Campos, A.B.A., Ribeiro, M.L., Solá, A.R., Moreira, M., 1998. Modelo tectónico da implantação do Complexo Eruptivo de Nisa (Alto Alentejo-Portugal). Actas do V Congresso Nacional de Geologia, Lisboa. Comunicações do Instituto Geológico e Mineiro 84 (1), B11-B14.

Pereira, M.F., Silva, J.B., 2001. The Portalegre-Esperança shear zone: sinistral transcurrent transpression along the Ossa-Morena/Central-Iberian zones boundary (Northeast Alentejo). Comunicações Instituto Geológico e Mineiro 88, 19-32.

Pereira, M.F., Silva, J.B., Chichorro, M., Moita, P., Santos, J.F., Apraiz, A., Ribeiro, C., 2007. Crustal growth and deformational processes in the Northern Gondwana margin: constraints from the Évora Massif (Ossa-Morena Zone, SW Iberia, Portugal). Geological Society of America Special Publication 423, 333-358 (Paper).

Pereira, M.F., Apraiz, A., Silva, J.B., Chichorro, M., 2008a. Tectonothermal analysis of high-temperature mylonitization in the Coimbra-Cordoba shear zone (SW Iberian Massif, Ouguela tectonic unit, Portugal): evidence of intra-continental transcurrent transport during the amalgamation of Pangea. Tectonophysics 461, 378-394.

Pereira, M.F., Chichorro, M., Williams, I.S., Silva, J.B., 2008b. Zircon U-Pb geochronology of paragneisses and biotite granites from the SW Iberian Massif (Portugal): evidence for a palaeogeographic link between the Ossa-Morena Ediacaran basins and the west African craton. In: Liegeóis, J.P., Nasser, E. (Eds.), The Boundaries of the West African Craton, 297. Geological Society of London Special Publication, pp. 385-404.

Pilar, L., 1966. Condições de formação do Jazigo Uranífero de Nisa. Comunicações Serviços Geológicos de Portugal 50, 51-83.

Pinto, M.S., Casquet, C., Ibarrola, E., Corrétge, L.G., Pereira, M.R., 1987. Síntese geocronológica dos granitóides do Maciço Hespérico. In: Bea, F., Carnicero, A., Gonzalo, J.C., López-Plaza, M., Rodrígues Alonso, M.D. (Eds.), Geologia de los
Granitoids y Rocas Asociadas del Macizo Hespérico. Libro de Homenagem a L.C.G. Figuerola. Editorial Rueda, Madrid, pp. 69-86.

Rapp, R.P., Watson, E.B., 1995. Dehydration melting of metabasalt at 8-32 kbar: implication for continental growth and crust-mantle recycling. Journal of Petrology 36, 891-932.

Ribeiro, M.L., 2001. Modelos de implantação dos granitos variscos Portugueses. Memórias da Academia das Ciências 39, 33-52.

Ribeiro, A., Quesada, C., Dallmeyer, R.D., 1990. Geodynamic evolution of the Iberian Massif. In: Dallmeyer, R.D., Martínez, E. (Eds.), Pre-Mesozoic Geology of Iberia. Springer-Verlag, Berlin, pp. 399-409.

Ribeiro, M.L. Moreira, A. Moreira, M.E., Moreira, M., Ferreira, P., Torres, L. 1995 Geoquímica das fácies internas do complexo eruptivo de Nisa (NE Alentejo). IV Congresso Nacional de Geologia. Memórias do Museu e Laboratório Mineralógico e Geológico, Universidade do Porto, 4, 801-804.

Roberts, S., Sanderson, D.J., Gumiel, P., Dee, S.J., 1991. Tectonic and fluid evolution of auriferous quartz veins from La Codosera area, SW Spain. Economic Geology 86, 1012-1022.

Silva, J.B., Pereira, M.F., 2004. Transcurrent continental tectonics model for the OssaMorena Zone Neoproterozoic-Paleozoic evolution, SW Iberian Massif, Portugal. International Journal Earth Sciences 93, 886-896.

Solá, A.R., 2007. Relações Petrogeoquímicas dos Maciços Graníticos do NE Alentejano, unpublished PhD dissertation, Universidade de Coimbra, Portugal, 405 pp.

Solá, A.R., Moreira, M., Moreira, M.E., Ribeiro, M.L., 1997. Relações geoquímicas e magnéticas nas fácies do Complexo Eruptivo de Nisa (NE Alentejo) I Congresso Ibérico de Geoquímica, Sória. CEDEx (Ed.) Centro de Estudios y Experimentación de Obras Públicas, España, 28-35.

Solá, A.R., Ribeiro, M.L., Moreira, M.E., Moreira, M., 1998a. Complexo eruptivo de Nisacartografia geoquímica e mecanismo de implantação. Actas do V Congresso Nacional de Geologia, Lisboa. Comunicações do Instituto Geológico e Mineiro 84 (1), B39-B42.

Solá, A.R., Ribeiro, M.L., Mateus, A., Ramos, J.F., 1998b. Circunstâncias geoquímicas e estruturais na base de defeitos de rocha ornamental (Região de Nisa-NE Alentejano). Actas do V Congresso Nacional de Geologia, Lisboa. Comunicações do Instituto Geológico e Mineiro 84 (1), B99-B102.

Solá, A.R., Pereira, M.F., Williams, I.S., Ribeiro, M.L., Neiva, A.M.R., Montero, P., Bea, F, Zinger, T., 2008. New insights from U-Pb zircon dating of Early Ordovician magmatism on the northern Gondwana margin: the Urra Formation (SW Iberian Massif, Portugal), Tectonophysics. doi:10.1016/j.tecto.2008.01.011.

Steiger, R.H., Jäger, E., 1977. Subcommission on geochronology: convention on the use of decay constants in geo- and cosmochronology. Earth and Planetary Science Letters 36, 359-362.

Valle Aguado, B., Azevedo, M.R., Schaltegger, U., Catalán, J.R., Nolan, J., 2005. U-Pb zircon and monazite geochronology of Variscan magmatism related to syn-convergence extension in Central Northern Portugal. Lithos 82, 169-184.

Valley. JW., 2003. Oxygen isotopes in zircon. In: Hanchar, J.M., Hoskin, PW.O. (Eds.) Zircon, Reviews in Mineralogy and Geochemistry, vol. 53. Mineralogical Society of America/Geochemical Society, Washington, DC, pp. 343-385.

Valley, J.W., Chiarenzelli, J.R., McLelland, J.M., 1994. Oxygen isotope geochemistry of zircon. Earth Planet Science Letters 126, 187-206.

Valley, J.W., Kinny, P.D., Schulze, D.J., Spicuzza, M.J., 1998. Zircon megacrysts from kimberlite: oxygen isotope variability among mantle melts. Contributions to Mineralogy and Petrology 133, 1-11

Williams, I.S., 2001. Response of detrital zircon and monazite, and their U-Pb isotopic systems, to regional metamorphism and host-rock partial melting, Cooma Complex, southeastern Australia. Australian Journal of Earth Sciences 48, 557-580.

Williams, I.S., Claesson, S., 1987. Isotopic evidence for the Precambrian provenance and Caledonian metamorphism of high grade paragneisses from the Seve Nappes, Scandinavian Caledonides. II. Ion microprobe zircon U-Th-Pb. Contributions to Mineralogy and Petrology 97, 205-217.

Williams, I.S., Goodge, J., Myrow, P., Burke, K., Kraus, J., 2002. Large scale sediment dispersal associated with the Late Neoproterozoic assembly of Gondwana. Abstracts of the 16th Australian Geological Convention, vol. 67, p. 238.

Wolf, M.B., Wyllie, P.J., 1994. Dehydration-melting of amphibolite at $10 \mathrm{kbar}$ : the effects of temperature and time. Contributions to Mineralogy and Petrology 115, 369-383.

Zeck, H.P., Wingate, M.T.D., Pooley, G., 2007. Ion microprobe U-Pb zircon geochronology of a late tectonic granitic-gabbroic rock complex within the Hercynian Iberian belt. Geological Magazine 144 (1), 157-177. 